\title{
Financial Crises and Exchange Rate Policy
}

\author{
Luca Fornaro* \\ This draft: July 2014 \\ First draft: February 2011
}

\begin{abstract}
This paper studies exchange rate policy in a small open economy model featuring an occasionally binding collateral constraint and Fisherian deflation. The goal is to evaluate the performance of alternative exchange rate policies in sudden stopprone economies. The key element of the analysis is a pecuniary externality arising from frictions in the international credit markets, which creates a trade-off between price and financial stability. The main result is that the appropriate exchange rate policy sustains the value of collateral and access to international credit markets during financial crises.
\end{abstract}

Keywords: Financial crises, Monetary Policy, Sudden Stops, Exchange Rate Regime, Nominal Wage Rigidities, Pecuniary Externalities.

JEL Classification Numbers: G01, E44, E52, F32, F34, F41.

* Centre de Recerca en Economia Internacional, Universitat Pompeu Fabra and Barcelona GSE, C/Ramon Trias Fargas, 25-27, 08005 Barcelona, Spain. E-mail: lfornaro@crei.cat. I am extremely grateful to Gianluca Benigno, Ethan Ilzetzki, Albert Marcet, Juan Pablo Nicolini, Michele Piffer, Christopher Pissarides, Romain Ranciere, Kevin Sheedy and Silvana Tenreyro for useful comments. I also thank seminar participants at the LSE, the PSE, the University of Surrey and the Paul Woolley Centre, and participants at the 13th ZEW Summer Workshop for Young Economists, the XVI Workshop on Dynamic Macroeconomics and the XXXVI Simposio de la Asociación Española de Economía. Financial support from the French Ministère de l'Enseignement Supérieur et de la Recherche, the ESRC, the Royal Economic Society and the Paul Woolley Centre is gratefully acknowledged. This paper previously circulated under the title "Financial Crises in Small Open Economies: The Role of Monetary Policy". 


\section{Introduction}

Since the financial liberalization wave of the 1980s, several countries have experienced financial crises characterized by sudden arrests of international capital inflows and sharp drops in output, consumption and asset prices. ${ }^{1}$ These episodes, known as sudden stops, have sparked great interest in the design of monetary and exchange rate policies in financially fragile economies. Should these economies let their exchange rate float or rather anchor it to a foreign currency? Should monetary policy be concerned only with its traditional objective of granting price stability or should it also care about financial stability?

In this paper, I address these questions focusing on a pecuniary externality originating from frictions on the international credit markets. I present a theoretical framework that shows how the combination of financial frictions and nominal rigidities gives rise to a trade-off between financial and price stability. The main result is that a narrow focus on offsetting nominal rigidities can lead to a sub-optimal monetary policy in sudden stopprone economies, and that it is optimal to use the exchange rate to sustain the value of collateral and access to international credit markets during financial crises.

I study a small open economy with imperfect access to the international financial markets, in the spirit of Mendoza (2010). Domestic agents borrow from foreign investors against collateral. Collateral consists in a physical asset used in production, land, valued at market price. When the collateral constraint binds a financial accelerator mechanism akin to Fisher's debt deflation arises: aggregate demand for land falls, the price of land drops and collateral declines. Because of this Fisherian deflation mechanism, when the collateral constraint binds the economy experiences a financial crisis driven by a sudden stop in capital inflows. Moreover, since domestic agents are atomistic they do not take into account the general equilibrium effect of their actions on the price of land and on the value of their collateral. This is the pecuniary externality that creates scope for policy interventions in the financial markets.

Wages are nominally rigid. ${ }^{2}$ During a financial crisis nominal wages fail to adjust

\footnotetext{
${ }^{1}$ Diaz-Alejandro (1985) is the classic reference on the link between financial liberalization and financial crises in emerging economies. Calvo et al. (2004) provide an overview of the facts characterizing sudden stop events.

${ }^{2}$ A growing body of evidence emphasizes how nominal wage rigidities represent a key transmission channel through which monetary policy affects the real economy. For instance, this conclusion is reached by Christiano et al. (2005) using an estimated medium-scale DSGE model of the US economy. Moreover, Olivei and Tenreyro (2007) show that monetary policy shocks in the US have a bigger impact on output if they occur during the first or second quarter of the year. They argue that this finding can be explained
} 
downward, potentially worsening the impact of financial turmoil on the real economy. The central bank can mitigate the downturn associated with a financial crisis by engineering an exchange rate depreciation that increases the competitiveness of the economy. Importantly, the stimulus provided by an exchange rate depreciation has a positive effect on the aggregate demand for land and on the value of collateral. Through this channel, exchange rate policy affects domestic agents' access to the international credit markets during crisis events.

I use the model to compare the performance of three alternative monetary rules: a fixed exchange rate rule and two types of floating exchange rate regimes. The first type of float considered is a policy of strict wage inflation targeting. This rule eliminates all the distortions arising from nominal wage stickiness and corresponds to the price stability rule of closed-economy sticky price models. The second type of float is a financial stability regime under which the central bank is allowed to respond to developments on the financial markets. Under this regime, the central bank depreciates the exchange rate when the collateral constraint binds, sustaining the collateral value of land and access to international financial markets.

The main result of the paper concerns the role of financial frictions in determining the welfare ranking between the wage inflation targeting rule and the financial stability regime. I show that in a version of the model in which the collateral constraint is replaced by a fixed borrowing limit, and hence in which Fisher's debt deflation channel is not present, wage inflation targeting is the regime that delivers higher welfare. This finding is in line with the well known result that, in models in which the only distortions come from monopolistic competition and nominal rigidities, a policy that corrects for nominal rigidities approximates well the optimal policy. ${ }^{3}$

I then show that the pecuniary externality implied by the Fisherian deflation mecha-

with the fact that most US firms adjust wages during the fourth quarter, and hence wages tend to be more rigid during the first half of the year. There is also evidence describing the role of nominal wage rigidities in exacerbating the downturn during financial crises, especially if coupled with fixed exchange rates. This point is made by Eichengreen and Sachs (1985) and Bernanke and Carey (1996) in the context of the Great Depression, while Schmitt-Grohé and Uribe (2011) document the importance of wage rigidities for the 2001 Argentine crisis and for the 2008-2009 recession in the Eurozone periphery. Micro-level evidence on the importance of nominal wage rigidities is provided by Fehr and Goette (2005), Gottschalk (2005), Barattieri et al. (2010) and Fabiani et al. (2010).

${ }^{3}$ Kollmann (2002) and Schmitt-Grohé and Uribe (2007) derive this result using models with monopolistic competition in the product market and nominal price rigidities. However, a similar logic should apply to models with monopolistic competition in the labor market and in which the presence of sticky wages is the only source of nominal rigidities. 
nism affects the welfare ranking among the policy rules considered. In fact, once the Fisherian deflation mechanism is introduced the financial stability regime welfare-dominates wage inflation targeting, because under the financial stability regime exchange rate policy mitigates the fall in the price of land and in capital inflows during crisis events. In contrast, the peg is always welfare dominated by the other two rules. This happens because during tranquil times the peg does not remove the distortions due to wage stickiness, while during crisis times pegging the exchange rate amplifies the fall in the price of land and in capital inflows compared to the other two regimes.

These welfare results are derived in a model in which crisis events are endogenous and rationally anticipated by agents, and in which monetary policy affects precautionary savings and crisis probability. ${ }^{4}$ In fact, the currency peg is the regime that stimulates more the accumulation of precautionary savings, followed by the policy of targeting wage inflation and by the financial stability regime. The intuition is simple: the more crises disrupt economic activity, the more agents accumulate precautionary savings to reduce the probability that the collateral constraint binds. Since the peg is the regime under which crises have the strongest impact on output and consumption, the peg is also the regime under which the accumulation of precautionary savings is stronger. Moreover, since crises are milder when the central bank adopts a financial stability rule, agents accumulate less precautionary savings under the financial stability regime than under a policy of strict wage inflation targeting.

This paper is related to two strands of the literature. The first one focuses on the design of monetary policy in financially fragile small open economies. Cespedes et al. (2004), Moron and Winkelried (2005) and Devereux et al. (2006) compare the performance of different monetary regimes in small open economies featuring financial market imperfections. Contrary to this paper, their models focus on business cycle fluctuations and are not suited to study economies occasionally subject to financial crises. Christiano et al. (2004), Cook (2004), Gertler et al. (2007), Braggion et al. (2007) and Curdia (2007) all use quantitative models to analyze the impact of monetary policy interventions during crisis times. In their frameworks crises are unexpected one-shot events, while this paper presents a model in which crises alternate with tranquil times and crisis probabilities are rationally anticipated by agents. This literature typically finds that the presence of

\footnotetext{
${ }^{4}$ Schmitt-Grohé and Uribe (2011) and Ottonello (2013) also study exchange rate policy in models in which crises are rationally anticipated by agents.
} 
financial frictions does not alter the welfare ranking among monetary policy rules, while the main insight of this paper is that financial frictions are a key determinant of which policy rule delivers higher welfare. Aghion et al. (2004), Caballero and Krishnamurthy (2003), Bordo and Jeanne (2002) and Benigno et al. (2011b) consider monetary economies featuring both tranquil periods and crises. However their focus is on static models, while the dynamics of debt accumulation play a key role in the model presented in this paper. ${ }^{5}$ This paper shares with Schmitt-Grohé and Uribe (2011) the focus on the performance of different exchange rate regimes in economies subject to the risk of experiencing a deep recession. The key difference is that their model does not feature a collateral constraint, while here the interaction between the exchange rate regime and Fisher's debt deflation is key.

The second strand of related literature employs dynamic real business cycle models featuring occasionally binding credit constraints and financial accelerator mechanisms, building on Mendoza $(2002,2010)$, to draw implications about policy conduct in small open economies prone to sudden stops. Examples are Benigno et al. (2011a), Bianchi (2011), Bianchi and Mendoza (2010) and Jeanne and Korinek (2010). The novelty of this paper with respect to this literature resides in the focus on monetary policy and on the interplay between Fisher's debt deflation and nominal wage rigidities. In a recent paper Ottonello (2013) studies exchange rate policy in a model in which collateral is based on current income, as in Mendoza (2002). In his setting a depreciation reduces the value of collateral, because it leads to a reduction in the foreign currency value of income derived from the nontradable sector, and exacerbates the pecuniary externality. Taken together, our contributions point toward the importance of empirically understanding what are the most important sources of collateral for the conduct of exchange rate policy.

The rest of the paper is structured as follows. Section 2 describes the analytical framework. Section 3 presents the results using numerical simulations. Section 4 provides a sensitivity analysis. Section 5 concludes.

\footnotetext{
${ }^{5}$ I refer to these frameworks as static because they consider economies that last two or three periods, in which the stock of external debt at the onset of a crisis is essentially taken as an exogenous variable.
} 


\section{Model}

Consider an infinite-horizon small open economy. Time is discrete and indexed by $t$. The economy is populated by a continuum of mass 1 of households that consume a single tradable good and engage in financial transactions with foreign investors. There is also a large number of competitive firms that produce the consumption good using factors of production supplied by the households, and a central bank that sets the nominal exchange rate as its policy instrument.

\subsection{Firms and production}

Firms are owned by the households. They are competitive, take all prices as given and produce the tradable consumption good according to the production function:

$$
Y_{t}=z_{t} F\left(L_{t}, K_{t}\right)
$$

where $Y_{t}$ denotes output and $z_{t}$ is a total factor productivity (TFP) shock, following a finite-state, stationary Markov process. $F(\cdot)$ is a decreasing-returns-to-scale production function, specified as: ${ }^{6}$

$$
F\left(L_{t}, K_{t}\right)=L_{t}^{\alpha_{L}} K_{t}^{\alpha_{K}}
$$

with $\alpha_{L} \geq 0, \alpha_{K} \geq 0$ and $\alpha_{L}+\alpha_{K}<1$. Firms produce using labor $L_{t}$ and land $K_{t}$. Both factors of production are purchased or rented from domestic households.

As in Obstfeld and Rogoff (2000), each household supplies a differentiated labor input. $L_{t}$ is a CES aggregate of the differentiated labor services:

$$
L_{t}=\left[\int_{0}^{1} L_{t}^{i \frac{\sigma-1}{\sigma}} d i\right]^{\frac{\sigma}{\sigma-1}}
$$

where $L_{t}^{i}$ denotes the labor input purchased from household $i$ and $\sigma>1$.

Purchasing power parity holds so $P_{t}=S_{t} P_{t}^{*}$. $P_{t}$ and $P_{t}^{*}$ are respectively the domestic and foreign currency price of the consumption good. $S_{t}$ denotes the nominal exchange rate, defined as the units of domestic currency needed to buy one unit of the foreign currency. For simplicity, I assume that $P_{t}^{*}$ is constant and normalize it to 1 . Hence, the

\footnotetext{
${ }^{6}$ Decreasing returns to scale in production can derive from the assumption that production also requires the input of managerial capital, of which each firm has a fixed supply normalized to 1.
} 
domestic currency price of the consumption good is equal to the nominal exchange rate $P_{t}=S_{t}$

In every period, the representative firm maximizes profits:

$$
\Pi_{t}=S_{t} Y_{t}-\int_{0}^{1} W_{t}^{i} L_{t}^{i} d i-R_{t}^{K} K_{t}
$$

where $W_{t}^{i}$ is the wage rate of household $i$ and $R_{t}^{K}$ is the rental rate of land, all expressed in units of the domestic currency.

The minimum cost of a unit of aggregate labor $L_{t}$ is given by:

$$
W_{t}=\left[\int_{0}^{1} W_{t}^{i 1-\sigma} d i\right]^{\frac{1}{1-\sigma}}
$$

which can be taken as the aggregate wage. Using this definition, profit maximization implies equality between factor prices and marginal productivities:

$$
\begin{gathered}
W_{t}=S_{t} z_{t} F_{L}\left(L_{t}, K_{t}\right) \\
R_{t}^{K}=S_{t} z_{t} F_{K}\left(L_{t}, K_{t}\right),
\end{gathered}
$$

where $F_{L}$ and $F_{K}$ are the derivatives of the production function respectively in $L_{t}$ and $K_{t}$. Finally, cost minimization gives the demand for household's $i$ labor:

$$
L_{t}^{i}=\left(\frac{W_{t}}{W_{t}^{i}}\right)^{\sigma} L_{t}
$$

\subsection{Households}

Households are the main actors in the economy. Each household derives utility from consumption $C_{t}^{i}$ and experiences disutility from labor effort $L_{t}^{i}$. The lifetime utility of a generic household $i$ is given by:

$$
E_{0}\left[\sum_{t=0}^{\infty} \beta^{t} U\left(C_{t}^{i}, L_{t}^{i}\right)\right]
$$

In this expression, $E_{t}[\cdot]$ is the expectation operator conditional on information available at time $t$ and $\beta$ is the subjective discount factor. The period utility function $U(\cdot)$ is 
assumed to be:

$$
U\left(C_{t}, L_{t}\right)=\frac{\left(C_{t}-\frac{L_{t}^{\omega}}{\omega}\right)^{1-\gamma}-1}{1-\gamma},
$$

with $\omega \geq 1$ and $\gamma \geq 1$, The period utility function takes the form introduced by Greenwood et al. (1988), often referred to as GHH preferences. GHH preferences eliminate the wealth effect on labor supply and are widely used in the quantitative literature on small open economies. ${ }^{7}$

Each household can trade in one period, non-state contingent foreign and domestic bonds. Both bonds are denominated in units of foreign currency. ${ }^{8}$ The foreign bond is traded with foreign investors and pays a fixed gross interest rate $R^{*}$, determined exogenously in the world market. ${ }^{9}$

The budget constraint of household $i$ in terms of the domestic currency can be written as:

$$
S_{t}\left(C_{t}^{i}+B_{t+1}^{* i}+B_{t+1}^{i}\right)+Q_{t}\left(K_{t+1}^{i}-K_{t}^{i}\right)=W_{t}^{i} L_{t}^{i}+R_{t}^{K} K_{t}^{i}+S_{t}\left(R^{*} B_{t}^{* i}+R_{t-1} B_{t}^{i}\right)+\Pi_{t} .
$$

The left-hand side of this expression represents the household's expenditure. This is given by the sum of consumption expenditure $S_{t} C_{t}^{i}$, investment in foreign bonds $S_{t} B_{t+1}^{* i}$, investment in domestic bonds $S_{t} B_{t+1}^{i}$ and net purchases of land $Q_{t}\left(K_{t+1}^{i}-K_{t}^{i}\right)$. $Q_{t}$ is the price of land at time $t$ in units of the domestic currency, while $K_{t}^{i}$ denotes the household's holdings of land at the beginning of period $t$.

The right-hand side captures the household's income. $W_{t}^{i} L_{t}^{i}$ is the household's labor income, $R_{t}^{K} K_{t}^{i}$ is the income derived from renting land to firms, while $S_{t} R^{*} B_{t}^{* i}$ and $S_{t} R_{t-1} B_{t}^{i}$ denote respectively the gross return on investment in foreign and domestic bonds made at time $t-1 . \Pi_{t}$ are the profits received from firms.

Foreign investors restrict loans so that total foreign debt taken by the household at time $t$ does not exceed a fraction $\kappa$ of the foreign currency value of the household's end

\footnotetext{
${ }^{7}$ Mendoza (1991) is an early example of a small open economy model using GHH preferences. Correia et al. (1995) compare different utility functions in a small open economy model and show that GHH preferences provide the best fit with the data.

${ }^{8}$ This assumption is meant to capture the widespread use of foreign currency denominated bonds in emerging markets. Since the foreign price of the consumption good is fixed, these bonds are equivalent to real bonds denominated in units of consumption or inflation-indexed bonds.

${ }^{9}$ See Fornaro (2012) for a model of sudden stops in which the world interest rate is determined endogenously.
} 
of period land holdings:

$$
-B_{t+1}^{* i} \leq \kappa \frac{Q_{t}}{S_{t}} K_{t+1}^{i}
$$

This constraint ensures that the loan-to-value ratio of domestic households does not exceed the limit $\kappa \cdot{ }^{10}$ This collateral constraint is meant to capture in reduced form an environment in which informational and institutional frictions affect the credit relationship between domestic and foreign agents. A constraint of this form arises if land can be used as collateral to mitigate the frictions on the international credit markets. Domestic bonds are not subject to the collateral constraint since they are not traded by foreign investors. ${ }^{11}$

I introduce nominal rigidities by assuming that each household has to set its nominal wage $W_{t}^{i}$ at the very start of the period, before uncertainty about the shocks is resolved. Each household acts as a monopolistic supplier of its labor input and sets its wage to maximize the expected present discounted value of utility (6), subject to the budget constraint (7) and firms' demand for its labor (5). The optimal wage satisfies:

$$
-E_{t-1}\left[U_{L}\left(C_{t}^{i}, L_{t}^{i}\right) L_{t}^{i}\right]=\frac{\sigma-1}{\sigma} W_{t}^{i} E_{t-1}\left[\frac{U_{C}\left(C_{t}^{i}, L_{t}^{i}\right)}{S_{t}} L_{t}^{i}\right]
$$

where $U_{C}(\cdot)$ and $U_{L}(\cdot)$ denote the derivative of the period utility function with respect to consumption and labor. At the margin, the expected disutility from an increase in labor effort, the left-hand side, is equal to the expected utility from higher revenue, the right-hand side.

Once wages are set, households are willing to satisfy firms' labor demand as long as the real wage, that is the wage expressed in units of the foreign currency, does not fall below the marginal rate of substitution between consumption and leisure:

$$
\frac{W_{t}^{i}}{S_{t}} \geq-\frac{U_{L}\left(C_{t}^{i}, L_{t}^{i}\right)}{U_{C}\left(C_{t}^{i}, L_{t}^{i}\right)}
$$

Given the pre-set wage and the realization of the productivity shock, each period the

\footnotetext{
${ }^{10}$ Similar collateral constraints are widely used in the literature on sudden stops. Mendoza (2010) shows that models featuring this form of financing constraints can reproduce quantitatively well both business cycles and sudden stop episodes in emerging economies.

${ }^{11}$ This assumption, along the lines of Caballero and Krishnamurthy (2001), captures an environment in which financial markets are segmented, for instance because domestic agents are better at enforcing repayment of loans than foreign investors As it will become clear later, this form of market segmentation is helpful in characterizing the central bank policy, but does not directly affect the dynamics of the economy.
} 
household chooses $C_{t}^{i}, B_{t+1}^{* i}, B_{t+1}^{i}$ and $K_{t+1}^{i}$ to maximize the expected present discounted value of utility (6), subject to the budget constraint (7) and the collateral constraint (8).

The optimality condition for $B_{t+1}^{i}$ can be written as:

$$
U_{C}\left(C_{t}^{i}, L_{t}^{i}\right)=\beta R_{t} E_{t}\left[U_{C}\left(C_{t+1}^{i}, L_{t+1}^{i}\right)\right]
$$

The optimal investment in domestic bonds is such that the marginal utility from period $t$ consumption is equal to the expected marginal utility from investing one unit of foreign currency in domestic bonds and consuming the return in period $t+1$.

The optimal choice for $B_{t+1}^{* i}$ is given by:

$$
U_{C}\left(C_{t}^{i}, L_{t}^{i}\right)=\beta R^{*} E_{t}\left[U_{C}\left(C_{t+1}^{i}, L_{t+1}^{i}\right)\right]+\mu_{t}^{i}
$$

where $\mu_{t}^{i}$ is the Lagrange multiplier on the collateral constraint, and by the complementary slackness condition:

$$
\mu_{t}^{i}\left(\kappa \frac{Q_{t}}{S_{t}} K_{t+1}^{i}+B_{t+1}^{* i}\right)=0
$$

The left-hand side of expression (12) is the marginal utility from spending one unit of foreign currency in period $t$ consumption. If the collateral constraint does not bind $\left(\mu_{t}^{i}=0\right)$ this is equated to the expected utility from investing one unit of foreign currency in foreign bonds and consuming the return in period $t+1$. When the collateral constraint binds $\left(\mu_{t}^{i}>0\right), B_{t+1}^{* i}$ is determined by the collateral that the household can offer to foreign investors, as stated by condition (13). In this case, the household is not free to borrow as much as it would like from foreign investors and the marginal utility of period $t$ consumption is bigger than the expected marginal utility cost of borrowing on the international credit market.

Combining equations (11) and (12) gives:

$$
R_{t}=\frac{R^{*}}{1-\mu_{t}^{i} / U_{C}\left(C_{t}^{i}, L_{t}^{i}\right)} .
$$

According to this equation, when the collateral constraint does not bind the interest rates on domestic and foreign bonds are equalized. However, when $\mu_{t}^{i}>0$ the interest rate on domestic bonds exceeds the interest rate paid on foreign bonds. The spread between the cost of borrowing on the domestic market and the world interest rate emerges because 
borrowing on the domestic credit market does not require collateral. Moreover, since $R_{t} / R^{*}$ is increasing in $\mu_{t}^{i}$, the spread can be interpreted as a measure of the cost derived from limited access to international credit markets or, more broadly, as a measure of stress in the financial markets.

The optimality condition for land $K_{t+1}^{i}$ is:

$$
\frac{Q_{t}}{S_{t}} U_{C}\left(C_{t}^{i}, L_{t}^{i}\right)=\beta E_{t}\left[U_{C}\left(C_{t+1}^{i}, L_{t+1}^{i}\right) \frac{R_{t+1}^{K}+Q_{t+1}}{S_{t+1}}\right]+\frac{Q_{t}}{S_{t}} \kappa \mu_{t}^{i}
$$

The left-hand side is the marginal cost in terms of utility of an extra unit of land investment. The right-hand side captures the marginal benefit from increasing the household's land holdings. The first term is the marginal return in terms of utility of renting a unit of land to firms in period $t+1$ and selling it at the end of the period. The second term is the value that the household gets from relaxing the collateral constraint by increasing its stock of land.

\subsection{Equilibrium}

The solution is symmetric across households and in equilibrium individual and aggregate per capita variables are identical. For example aggregate consumption per capita $C_{t}$ is given by:

$$
C_{t}=\int_{0}^{1} C_{t}^{i} d i=C_{t}^{i}
$$

where the last equality comes from the fact that each household makes the same choices in equilibrium. Similarly, in equilibrium the aggregate net foreign asset position of the economy $B_{t}^{*}$ is:

$$
B_{t}^{*}=B_{t}^{* i}
$$

and the individual and aggregate wage coincide:

$$
W_{t}=W_{t}^{i}
$$

To derive the resource constraint of the economy, notice that since the domestic bond is traded only among domestic households its net supply must be equal to zero, i.e. equilibrium on the domestic bond market requires $B_{t}^{i}=0$ for every $t$. The aggregate stock of land is assumed constant and equal to $K$, so that in equilibrium the households' 
net purchases of land must be zero. Using these equilibrium conditions, the expression for firms' profits (2) and the household's budget constraint (7) gives the aggregate resource constraint of the economy:

$$
C_{t}+B_{t+1}^{*}=Y_{t}+R^{*} B_{t}^{*}
$$

This expression says that the aggregate expenditure of the economy, the sum of consumption plus investment in foreign bonds, must be equal to aggregate income, which is given by the sum of the gross domestic product $Y_{t}$ plus the gross return on foreign bonds purchased during the previous period.

Finally, market clearing for the factors of production requires:

$$
\begin{gathered}
L_{t}=L_{t}^{i} \\
K_{t}=K_{t}^{i}=K .
\end{gathered}
$$

We are now ready to define a rational expectations equilibrium as a set of stochastic processes $\left\{C_{t}^{i}, C_{t}, B_{t+1}^{* i}, B_{t+1}^{*}, L_{t}^{i}, L_{t}, K_{t+1}^{i}, K_{t+1}, Y_{t}, W_{t}^{i}, W_{t}, R_{t}^{K}, Q_{t}, \mu_{t}^{i}, S_{t}\right\}_{t=0}^{\infty}$ satisfying (1), (3)-(4), (9)-(20), given the exogenous process $\left\{z_{t}\right\}_{t=0}^{\infty}$, the central bank's policy $\left\{S_{t}\right\}_{t=0}^{\infty}$ and initial conditions $B_{0}^{*}$ and $z_{-1} \cdot{ }^{12}$

\subsection{Central bank and exchange rate policy}

The central bank uses the nominal exchange rate as the monetary policy instrument. I focus the analysis on a central bank that credibly commits to a policy rule at the start of period 0 , before period 0 wages are set, and then maintains that policy forever.

I consider three policy rules. First, I consider a policy that replicates the flexible wage equilibrium. This rule offsets all the distortions originating from nominal rigidities and captures the traditional price stability objective of central banks. As shown in the appendix, the flexible wage equilibrium can be implemented by setting the exchange rate according to:

$$
S_{t}=\bar{S} z_{t}^{\xi_{z}}
$$

with $\xi_{z} \equiv(1-\omega) /\left(\omega-\alpha_{L}\right)$. Due to the GHH preferences, it is sufficient for the exchange

\footnotetext{
${ }^{12} z_{-1}$ has to be included among the initial conditions because it is used by households to form expectations in the wage setting equation (9).
} 
rate to respond to TFP shocks in order to replicate the equilibrium under flexible wages. Under this regime the exchange rate depreciates in response to a low realization of the TFP shock, and viceversa. This policy rule implies zero nominal wage inflation, i.e. $W_{t}=W_{t+1}$ for all $t$. Hence, I will refer to this regime as strict wage inflation targeting.

Second, I consider a financial stability regime, in which the central bank is allowed to respond to developments on the financial markets. To operationalize this concept, I consider a policy rule in which the exchange rate responds to TFP shocks and to the spread between domestic and foreign bonds:

$$
S_{t}=\bar{S} z_{t}^{\xi_{z}}\left(\frac{R_{t}}{R^{*}}\right)^{\xi_{R}}
$$

This rule implements the flexible wage allocation during periods in which the collateral constraint does not bind for any realization of the TFP shock. Instead, during periods in which the collateral constraint might bind the central bank is allowed to deviate from the flexible wage allocation. ${ }^{13}$ This rule captures in a simple form a financial stability objective for the central bank.

The third regime considered is a perfectly credible currency peg in which $S_{t}=\bar{S}$ for all $t$. This policy is interesting because it captures the case of dollarized countries or of countries belonging to a monetary union. Moreover, it will be used to calibrate the model using data from Eurozone peripheral countries.

\subsection{Exchange rate policy and Fisherian deflation}

Before proceeding to the numerical results, it is useful to build some intuition about the impact of exchange rate policy on output and collateral. To this end, in this section I present a partial equilibrium analysis that provides insights on the central bank's ability to affect the value of collateral, and so access the to international credit markets.

Let us start by deriving the impact of an exchange rate depreciation on employment and output. Once wages are set, equilibrium labor is determined by firms' labor demand,

\footnotetext{
${ }^{13}$ More formally, for any state $\left\{B_{t}^{*}, z_{t-1}\right\}$ such that the collateral constraint does not bind for any realization of $z_{t}$ this rule implements the flexible wage allocation. Instead, in states $\left\{B_{t}^{*}, z_{t-1}\right\}$ such that the collateral constraint binds for some realization of $z_{t}$, the rule allows the central bank to deviate from the flexible wage allocation.
} 
equation (3), which can be written as: ${ }^{14}$

$$
L_{t}=\left(\alpha_{L} K^{\alpha_{K}} z_{t} \frac{S_{t}}{W_{t}}\right)^{\frac{1}{1-\alpha_{L}}}
$$

This expression makes clear that a depreciation, i.e. a rise in $S$, has a positive impact on employment and output, because it decreases the cost of labor in terms of the consumption good, inducing firms to increase employment and production.

To trace the impact of a depreciation on the value of land and so on collateral, combine equations (14) and (12) to write the equilibrium real price of land as:

$$
\frac{Q_{t}}{S_{t}}=\frac{\beta E_{t}\left[U_{C}\left(C_{t+1}, L_{t+1}\right) \frac{R_{t+1}^{K}+Q_{t+1}}{S_{t+1}}\right]}{(1-\kappa) U_{C}\left(C_{t}, L_{t}\right)+\kappa \beta R^{*} E_{t}\left[U_{C}\left(C_{t+1}, L_{t+1}\right)\right]}
$$

Since $U_{C}\left(C_{t}, L_{t}\right)$ is decreasing in $C_{t}$, this equation gives a positive relationship between the real price of land and current consumption. This is due to the households' desire to smooth consumption over time, which implies that the rate at which future returns from land holdings are discounted is decreasing in current consumption.

In states in which the collateral constraint binds the resource constraint implies another positive relationship between consumption and land price. To see this point combine the resource constraint (18) and the binding collateral constraint (8) to obtain:

$$
C_{t}=z_{t} F\left(L_{t}, K_{t}\right)+R^{*} B_{t}+\kappa \frac{Q_{t}}{S_{t}} K
$$

To gain intuition about this equation, consider that an increase in the price of land corresponds to an increase in the value of collateral that domestic households can offer to foreign investors. The positive relationship between consumption and land price is due to the fact that when households are borrowing constrained they respond to the increase in the value of their collateral by borrowing more to finance current consumption.

Equations (21) and (22) form the basis of the Fisherian deflation mechanism described by Mendoza (2010). ${ }^{15}$ In states in which the collateral constraint binds, households discount at a high rate future returns from land, depressing land price and the value of collateral. Moreover, lower collateral is associated with lower consumption and a

\footnotetext{
${ }^{14}$ This is true as long as condition (10) does not bind, which is always the case in the numerical simulations presented below.

${ }^{15}$ See also Bianchi and Mendoza (2010).
} 
higher discount factor, creating a vicious cycle of falling capital inflows, consumption and collateral value. It is because of this amplification mechanism that the economy falls into a crisis when the collateral constraint binds.

A depreciation can help in counteracting the Fisherian deflation. Remember that a depreciation has a positive impact on output. According to equation (22), when the collateral constraint binds the increase in output generated by a depreciation leads to a rise in consumption. In turn, the increase in consumption induces households to reduce the rate at which they discount future returns from land, driving up land price. Hence, when the collateral constraint binds a depreciation not only increases employment and production, but also sustains land price and the value of collateral.

Does the central bank have an incentive to deviate from its traditional objective of offsetting nominal rigidities in order to exploit its ability to influence land price and the value of collateral? As discussed by Bianchi and Mendoza (2010) and Korinek (2012), the presence of an asset price in the collateral constraint and the fact that atomistic households do not internalize the impact of their decisions on asset prices introduce a pecuniary externality that might call for policy intervention. In the rest of the paper I show that the central bank should use the exchange rate to partly correct for the pecuniary externality arising from the collateral constraint.

\section{Parameterization and results}

The model cannot be solved analytically and I analyze its properties using numerical simulations. A period in the model corresponds to one year. The values of the parameters are chosen using annual data from five small open economies belonging to the Eurozone periphery: Greece, Ireland, Italy, Portugal and Spain. For each country the period considered starts with the year of adoption of the Euro and ends in $2010{ }^{16}$ I focus on this sample because it features a homogeneous exchange rate policy. The calibration strategy consists in choosing values for the parameters so that the model with monetary policy characterized by a currency peg matches some key aspects of the countries in the sample.

\footnotetext{
${ }^{16}$ For Ireland, Italy, Portugal and Spain the period considered is 1999-2010, while for Greece it is 2001-2010. Unless otherwise stated, the data come from Eurostat and from the World Development Indicators.
} 


\subsection{Parameterization}

The risk aversion parameter is set at $\gamma=2$, a standard value in the real business cycle literature. The Frisch elasticity of labor supply $1 /(\omega-1)$ is set equal to 1 , in line with evidence by Kimball and Shapiro (2008). As in Bianchi and Mendoza (2010), the world interest rate is set to $R^{*}=1.028$, a reasonable value for the interest rate charged to small open economies during tranquil times, and the discount factor $\beta$ is set to 0.96 , a standard value. ${ }^{17}$ I assume a labor share in GDP of 0.64 and so $\alpha_{L}=0.64$, and I set $\alpha_{K}=0.05$ following Bianchi and Mendoza (2010). The parameter $\sigma$ is set to 3 as in Smets and Wouters (2003). The stock of land $K$ is normalized to one without loss of generality.

The productivity shock $z_{t}$ follows a log-normal AR(1) process $\log \left(z_{t}\right)=\rho \log \left(z_{t-1}\right)+\eta_{t}$. This process is approximated with the quadrature procedure of Tauchen and Hussey (1991) using 5 nodes. The first order autocorrelation $\rho$ and the standard deviation of the productivity shock $\sigma_{z}$ are set so that the model economy under a peg reproduces the average across the five sample countries of the corresponding moments for the cyclical component of GDP per capita (which are respectively 3.1 percent and 0.65). ${ }^{18}$ This procedure yields $\rho=0.87$ and $\sigma_{z}=0.0173$.

The parameter $\kappa$ is set so that the unconditional probability of experiencing a crisis in the currency peg version of the model economy is 5.5 percent, in line with the observed frequency of sudden stops in the cross-country data set of Eichengreen et al. (2006). To be consistent with their definition, a crisis in the model occurs when the credit constraint binds and this leads to an improvement in the current account that exceeds one standard deviation. This calibration results in a value of $\kappa$ equal to 0.36 .

The last two parameters to be set concern the exchange rate rule. The exchange rate target $\bar{S}$ is normalized to one. I set $\xi_{R}$, the parameter that determines the response of the exchange rate to the spread between domestic and foreign bonds under the financial stability regime, to 0.2 . This is the value that maximizes welfare under the financial

\footnotetext{
${ }^{17}$ Under a currency peg, this value for the discount factor implies an average net foreign assets-to-GDP ratio of 46 percent, not far from 41 percent, which is the average net foreign assets-to-GDP ratio across the five sample countries during the period since Euro adoption up to 2007. Data are from Lane and Milesi-Ferretti (2007).

${ }^{18}$ More precisely, for the five countries in the sample I computed the logarithm of per capita GDP during the period 1960-2010 and removed a smooth trend using the Hodrick-Prescott filter with a smoothing parameter of 100. I then computed for each country the standard deviation and the first order autocorrelation of the detrended series, restricting the sample to the years since the adoption of the Euro. The average standard deviation across the countries in the sample is 3.1 percent, while the average first order autocorrelation is 0.65 .
} 
Table 1: Parameters

\begin{tabular}{lll}
\hline & Value & Source/Target \\
\hline Risk aversion & $\gamma=2$ & Standard value \\
Frisch elasticity of labor supply & $1 /(\omega-1)=1$ & Kimball and Shapiro (2008) \\
World interest rate & $R^{*}=1.028$ & Standard value \\
Discount factor & $\beta=0.96$ & Standard value \\
Labor share in output & $\alpha_{L}=0.64$ & Labor share in GDP $=64 \%$ \\
Land share in output & $\alpha_{K}=0.05$ & Bianchi and Mendoza (2010) \\
Elasticity of demand for labor & $\sigma=3$ & Smets and Wouters $(2003)$ \\
Stock of land & $K=1$ & Normalization \\
TFP process & $\sigma_{z}=0.0173, \rho=0.87$ & Std. dev. and autoc. of GDP \\
Credit coefficient & $\kappa=0.36$ & Frequency of crises $=5.5 \%$ \\
Exchange rate target & $\bar{S}=1$ & Normalization \\
Exchange rate response to spread & $\xi_{R}=0.2$ & Max. welfare \\
\hline
\end{tabular}

stability regime in the benchmark parameterization. This coefficient implies that under the financial stability regime it is optimal for the central bank to depreciate the exchange rate when the collateral constraint binds, and hence to exploit its ability to sustain the price of land and the value of collateral during financial crises.

\subsection{Policy functions}

The solution is approximated numerically by applying the time iteration method proposed by Coleman (1990). This global solution method preserves the nonlinearities induced by the occasionally binding collateral constraint. The state of the economy in period $t \geq 0$ is given by the triplet $\left\{B_{t}^{*}, z_{t-1}, z_{t}\right\}$. The previous period productivity shock $z_{t-1}$ must be included among the state variables because it is used by households at the start of the period to form the expectations needed to set their wages. Details about the numerical solution method can be found in the appendix.

Figure 1 shows the decision rules for next period foreign bonds, consumption, land price, employment and exchange rate as a function of the current holdings of foreign bonds and of the exchange rate regime. ${ }^{19}$

Due to the Fisherian deflation mechanism, the policy functions for next period foreign bonds are V-shaped. To the right of the kink the collateral constraint does not bind and investment in foreign bonds is increasing in the holdings of bonds at the start of the period, because when the collateral constraint does not bind households' savings are increasing

\footnotetext{
${ }^{19}$ The decision rules are conditional on $z_{t-1}$ being equal to the mean value of TFP and $z_{t}$ being one standard deviation below mean.
} 

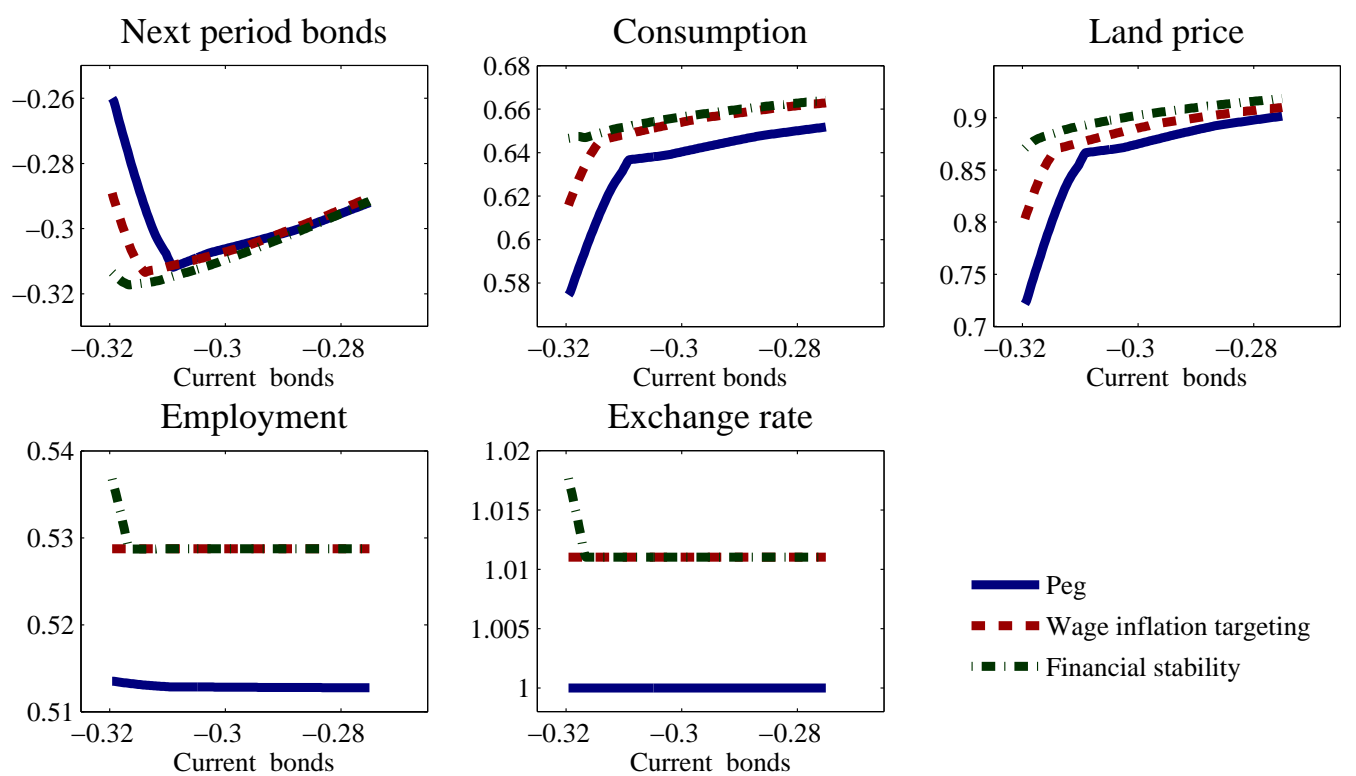

Figure 1: Policy functions

in wealth. To the left of the kink the collateral constraint binds and the relation between current and next period bonds becomes negative, because lower values of start-of-period wealth are associated with lower consumption and land price, and a tighter collateral constraint. $^{20}$

Among the three exchange rate regimes considered, the financial stability regime is the one under which high levels of external debt can be supported without generating large drops in consumption and land price. This happens because under the financial stability regime the central bank depreciates the exchange rate when the collateral constraint binds, which sustains employment, consumption and land price. Conversely, the currency peg is the regime associated with larger drops in consumption and land price at high levels of foreign debt. To understand why this is the case it is useful to turn to a crisis event analysis.

\subsection{Crisis event analysis}

This section describes how the exchange rate regime affects the behavior of the economy during crises. To compare the response of economies with different exchange rate regimes to a typical crisis event I use the following procedure. I simulate the model economy under a currency peg for 100000 periods, drop the first 1000 periods and then collect all

\footnotetext{
${ }^{20}$ See Bianchi and Mendoza (2010) for a detailed analysis.
} 
the crisis events, that is periods in which the collateral constraint binds and the current account-to-GDP ratio exceeds one standard deviation. Then I construct five year windows centered around each crisis episode and calculate the median productivity shock across all of these event windows in each year $t-2$ to $t+2$, the median holdings of foreign bonds at $t-2$ and the median productivity shock at $t-3$. Finally, I feed this sequence of shocks and initial values for the state variables to the decision rules of each model economy and compute the corresponding endogenous variables. The results are shown in figure 2. All the variables are in percentage deviations from their ergodic mean except for the current account-to-GDP ratio, the exchange rate and the spread between between the domestic and world interest rates.

Let us start by describing the crisis dynamics under a currency peg, which correspond to the solid lines in figure 2. Initially the economy is on a steady state in which the productivity shock is equal to its mean value, the collateral constraint is not binding, the spread between the domestic and the world interest rate is zero and net foreign assets are constant. In period $t$ the economy is hit by a negative TFP shock, the collateral constraint becomes binding, as signaled by the rise in the spread, and the economy enters a crisis.

During the crisis GDP drops by more than 4 percentage points below its ergodic mean. The drop in GDP happens because of two effects. First, the negative TFP shock induces a fall in output for a given amount of factors of production employed. Second, the combination of nominal wage rigidities and fixed exchange rate prevents real wages from adjusting downward to accommodate the fall in firms' labor demand caused by the drop in TFP. The result is a fall in employment of about 4 percentage points.

Consumption decreases by more than 7 percentage points below trend. Consumption falls by more than GDP because the binding collateral constraint forces households to reduce their debt, as captured by the rise in the current account-to-GDP ratio. Finally, the Fisherian deflation mechanism generates a fall in the foreign currency price of land of more than 8 percentage points.

During the fourth period productivity remains below trend, but output and consumption recover because of two effects. First, since the TFP shock is persistent, after the first period of productivity below trend households revise downward their expectations of future labor demand and lower their wages accordingly. The drop in wages helps the 
TFP

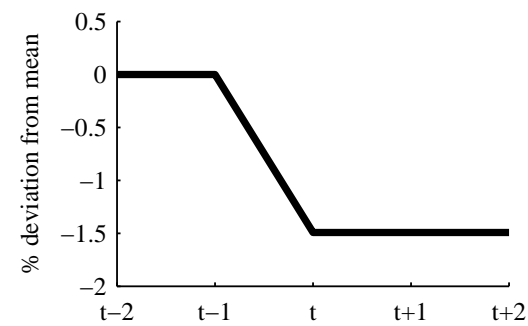

Current account/GDP

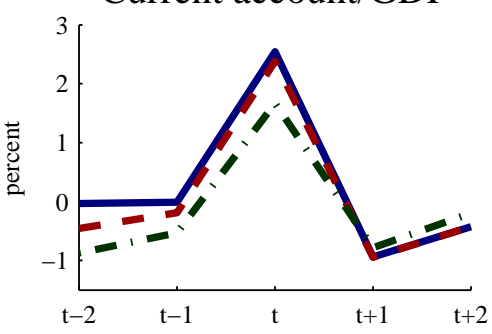

Real wage

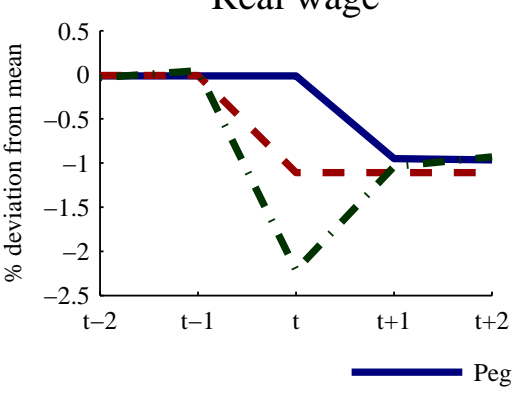

GDP

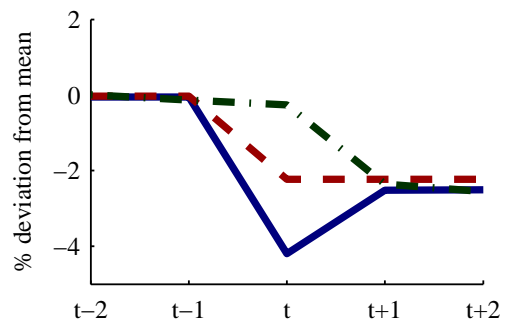

Land price

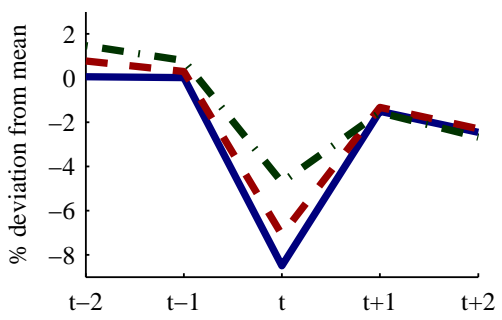

Exchange rate
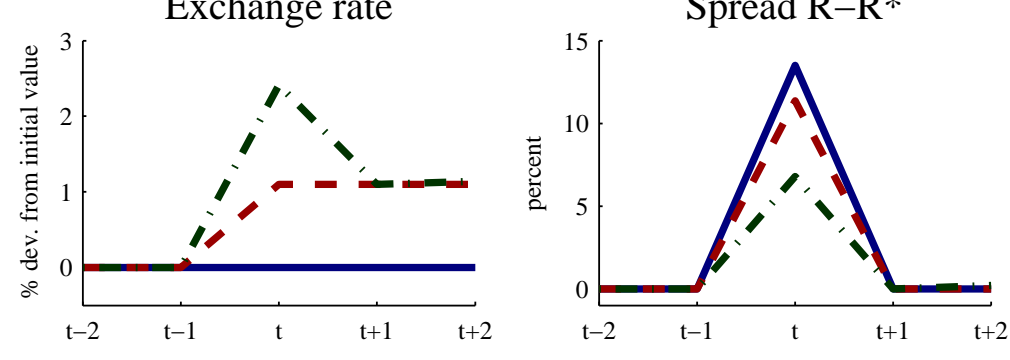

Figure 2: Crisis event analysis

recovery with its positive impact on employment and GDP. ${ }^{21}$ Second, the sudden stop causes a sharp decrease in foreign debt, which relaxes the collateral constraint so that it is no longer binding, allowing households to increase their imports of the consumption good.

The dashed lines in figure 2 illustrate the behavior of the economy when the central bank implements a policy of strict wage inflation targeting. The economy with wage inflation targeting and the currency peg exhibit similar dynamics in the two years before the crisis. However, when in period $t$ the crisis hits the behavior of the two economies diverges.

Under wage inflation targeting the central bank lets the exchange rate depreciate during the sudden stop, in order to reduce real wages in response to the fall in firms' demand for labor. The depreciation affects the economy through several channels. First,

\footnotetext{
${ }^{21}$ The fast recovery is due to the fact that wages can adjust after one period. As shown by SchmittGrohé and Uribe $(2011,2013)$, in presence of a currency peg persistent downward wage rigidities can give rise to long lasting recessions.
} 

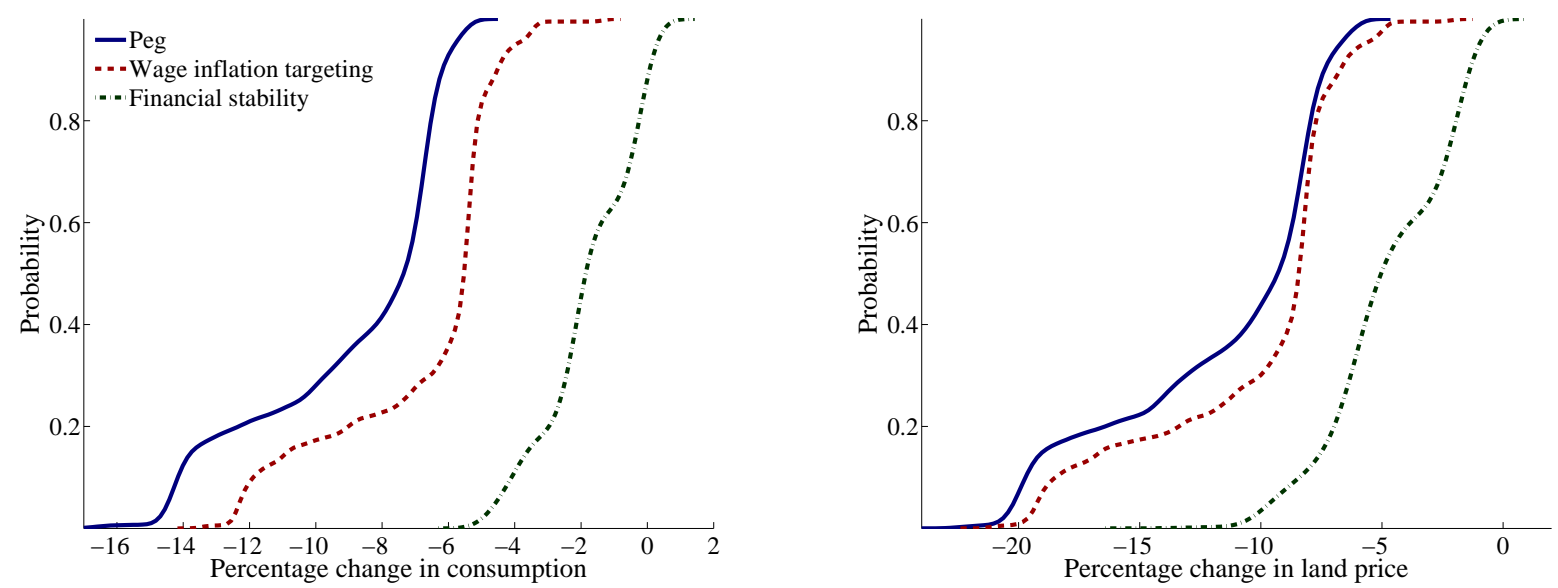

Figure 3: Cumulative distribution of impact effect of crises on consumption (left panel) and land price (right panel)

the associated decrease in the cost of labor pushes firms to increase employment and production. Moreover, the increase in output allows households to consume more. In turn, the increase in consumption sustains the demand for land and its price and relaxes households' collateral constraints. Indeed, the depreciation interacts with the financial amplification mechanism and produces a virtuous cycle of increases in consumption, land price and capital inflows.

The outcome is that under wage inflation targeting the impact of the sudden stop on output, consumption and land price is milder than under the currency peg. GDP falls by only 2 percent below its ergodic mean, consumption falls by 5 percent below its mean and the price of land falls by 7 percentage points below its mean. The spread spikes up during the crisis, but the increase is smaller than in the case of the currency peg.

The dash-dotted lines show the behavior of the economy under the financial stability regime. Under this regime the exchange rate depreciates during the sudden stop by more than under wage inflation targeting, because of the endogenous response of the exchange rate to the rise of the spread.

The reduction in the cost of labor is sufficiently large so that employment rises above trend during the crisis and output barely falls below its ergodic mean. Also, the financial stability regime exhibits the smallest drops in consumption, which falls by just 2 percent below trend, and land price, which falls by nearly 5 percent below its ergodic mean, compared to the other two regimes.

The event analysis suggests that the financial stability regime fares better than the 


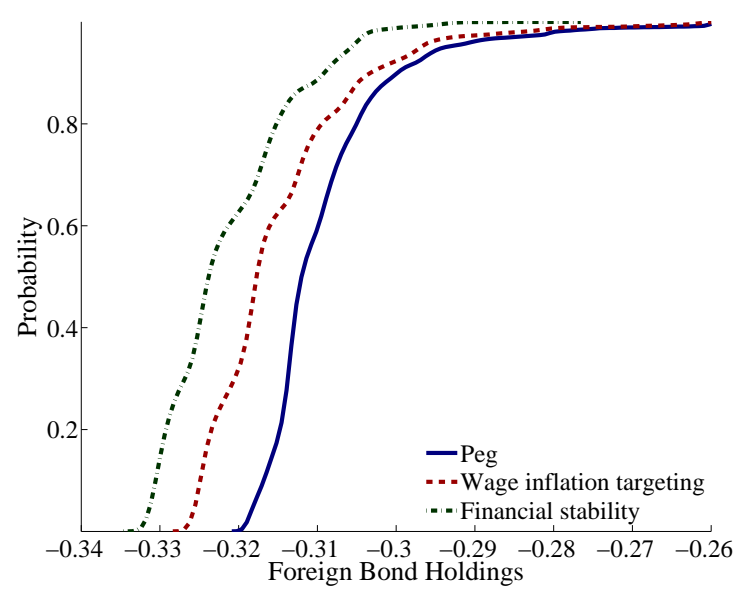

Figure 4: Ergodic cumulative probability distribution of foreign bond holdings

other two rules in stabilizing consumption and the price of land during sudden stops. Figure 3 further illustrates this point by showing the ergodic cumulative probability distribution of the response of consumption and land price to sudden stops under the three exchange rate policies, expressed as percentage deviations from their ergodic means. ${ }^{22}$ The figure shows that both the economy with wage inflation targeting and the currency peg assign non-trivial probabilities, respectively 25 percent and 95 percent, to consumption drops of more than 6 percent, the maximum fall in consumption experienced during a crisis by the economy with the financial stability regime. Similarly, the financial stability regime assigns a negligible probability to falls in land price below 10 percent, while this happens with more than a 20 percent probability under wage inflation targeting and with almost a 40 percent probability under a peg.

\subsection{Debt accumulation, leverage and crisis probability}

The exchange rate regime not only affects the economy during sudden stops, but it also has an impact on debt accumulation during tranquil times and on the probability that the economy falls into a crisis.

Figure 4 displays the ergodic cumulative probability distribution of foreign bond holdings for the three policy rules considered. Both the economy with wage inflation targeting and the one with the financial stability regime tend to reach higher levels of foreign debt

\footnotetext{
${ }^{22}$ To construct this figure I performed for each model economy a 100000-period long simulation, dropped the first 1000 periods and collected all the crisis events. The figure plots for each economy the cumulative probability distribution function of the percentage deviations of consumption and land price from their ergodic means conditional on the economy being in a crisis.
} 
Table 2: Leverage and crisis probability

\begin{tabular}{lccc}
\hline & $\begin{array}{c}\text { Wage inflation } \\
\text { targeting }\end{array}$ & $\begin{array}{c}\text { Financial } \\
\text { stability }\end{array}$ & $\begin{array}{c}\text { Currency } \\
\text { peg }\end{array}$ \\
\hline Mean leverage & 35 & 35.5 & 34.5 \\
Crisis probability & 5.9 & 10.6 & 5.5 \\
\hline
\end{tabular}

Note: Leverage is defined as $-S_{t} B_{t+1}^{*} / Q_{t} K$. A crisis event is defined as a period in which the collateral constraint binds and the current account-to-GDP ratio exceeds one standard deviation.

than the peg. For instance, the probability of experiencing levels of foreign debt higher than the maximum attained by the currency peg is around 30 percent for the economy with wage inflation targeting and around 60 percent for the one with the financial stability regime.

The reluctance of agents living under a currency peg to reach high levels of foreign debt can be explained with the fact that a higher level of foreign debt increases the chances that a negative shock makes the collateral constraint bind. Since episodes of binding collateral constraint are more disruptive under a currency peg than under the two other monetary regimes, households living under a peg take smaller levels of foreign debt to reduce the risk of entering a crisis. Consistent with this, the economy with the financial stability rule, which is the regime under which crises have the mildest effects, reaches high levels of foreign debt more often than the economy with wage inflation targeting.

By affecting borrowing decisions, the exchange rate regime has also an impact on the leverage ratio, defined as the foreign debt-to-land value ratio. ${ }^{23}$ Table 2 shows that the financial stability regime features the highest mean leverage ratio (35.5 percent), followed by the economy with wage inflation targeting (35 percent) and by the currency peg (34.5 percent). Hence, there is a negative relationship between the severity of crises and the mean leverage ratio.

Moreover, through its impact on households' debt decisions, the exchange rate regime influences the probability that the economy enters a crisis. Table 2 shows that the unconditional probability of entering a crisis is 5.5 percent for the economy with a fixed exchange rate, while the crisis probability is 5.9 percent for the economy with wage inflation targeting and 10.6 for the economy with the financial stability rule. This result points toward the importance of considering the impact of policy not only during crisis times, but also on decisions taken during normal times that affect the probability of

\footnotetext{
${ }^{23}$ Formally, leverage at time $t$ is defined as $-S_{t} B_{t+1}^{*} / Q_{t} K$.
} 
experiencing crises.

\subsection{Long run moments}

This section documents how the exchange rate regime affects the business cycle moments of the economy. Table 3 displays the long-run business cycle moments for the three policies considered, computed using each economy's ergodic distribution. The economy with the currency peg exhibits the highest business cycle variability in GDP, labor and consumption, signaling the role of shock absorber that flexible exchange rates perform in the model. ${ }^{24}$ The economy with the financial stability rule is characterized by lower volatility in GDP and consumption compared to the economy with wage inflation targeting, but by higher volatility in employment, pointing at the existence of a trade off between consumption and employment volatility. This can be explained with the fact that the financial stability regime stabilizes consumption during financial crises by stimulating employment.

The model produces a higher variability in GDP than in consumption, a typical feature of emerging markets subject to the risk of financial crises, as highlighted by Neumeyer and Perri (2005). The high volatility of consumption is due to the fact that the Fisherian deflation mechanism interferes with households' desire to smooth consumption over time. This can be seen by looking at the cyclicality of the trade balance-to-GDP ratio. In absence of frictions in the credit market the trade balance would be procyclical, because households would smooth the impact of productivity shocks on consumption by decreasing net exports during periods of low productivity. Instead, the binding collateral constraint forces agents to reduce their foreign borrowing, and hence to increase their net exports, when productivity is low generating a countercyclical trade balance-to-GDP ratio. By looking at the cyclicality of the trade balance we can see that consumption smoothing works worst under the peg, which has the highest negative cyclicality of the trade-balanceto-GDP ratio, while financial stability is the regime that guarantees better consumption smoothing, since its trade balance-to-GDP ratio is mildly procyclical.

The Fisherian deflation mechanism also affects the business cycle moments of land price and leverage. Land price is much more volatile than GDP and strongly procyclical under the three regimes. The financial stability rule is the regime with the lowest land

\footnotetext{
${ }^{24}$ For empirical evidence on the shock-absorbing role of flexible exchange rates see Broda (2004).
} 
Table 3: Long Run Moments

\begin{tabular}{|c|c|c|c|c|c|c|c|c|c|}
\hline & \multicolumn{3}{|c|}{$\begin{array}{l}\text { Standard } \\
\text { deviation }\end{array}$} & \multicolumn{3}{|c|}{$\begin{array}{l}\text { Correlation } \\
\text { with GDP }\end{array}$} & \multicolumn{3}{|c|}{ Autocorrelation } \\
\hline & WIT & FS & PEG & WIT & FS & PEG & WIT & FS & PEG \\
\hline GDP & 2.43 & 2.29 & 3.11 & 1.00 & 1.00 & 1.00 & 0.87 & 0.87 & 0.65 \\
\hline Consumption & 2.86 & 2.34 & 3.54 & 0.91 & 0.93 & 0.94 & 0.58 & 0.83 & 0.48 \\
\hline Trade balance/GDP & 0.95 & 0.65 & 0.96 & -0.13 & 0.14 & -0.19 & -0.19 & -0.25 & -0.20 \\
\hline Employment & 1.22 & 1.49 & 2.51 & 1.00 & 0.78 & 0.95 & 0.87 & 0.36 & 0.34 \\
\hline Leverage & 2.27 & 1.56 & 3.09 & -0.41 & -0.54 & -0.70 & 0.37 & 0.47 & 0.46 \\
\hline Land price & 4.01 & 3.36 & 4.28 & 0.86 & 0.79 & 0.89 & 0.49 & 0.65 & 0.48 \\
\hline Exchange rate & 1.22 & 1.54 & 0.00 & -1.00 & -0.78 & - & 0.87 & 0.67 & - \\
\hline
\end{tabular}

Note: WIT stands for the economy with strict wage inflation targeting, FS stands for the financial stability regime and PEG stands for the currency peg. Autocorrelation refers to the first-order autocorrelation. Leverage is defined as $-S_{t} B_{t+1}^{*} / Q_{t} K$.

price volatility, while the peg exhibits the highest volatility in land price. Also leverage is most volatile under the peg, while the lowest volatility is attained under the financial stability regime. Leverage is countercyclical under the three policy regimes, due to the fact that when the collateral constraint binds, and thus when leverage has reached its maximum $\kappa$, GDP tends to fall.

The exchange rate is more volatile under the financial stability regime, compared to the economy with wage inflation targeting. Both regimes exhibit small volatilities in the exchange rate compared to data from small open economies, in accordance with the well known difficulty of DSGE models in accounting for the volatility of nominal exchange rates (see for example Kollmann (2002) and Gertler et al. (2007)). In both regimes the exchange rate is countercyclical, because negative productivity shocks are associated with depreciations, and features a positive first-order autocorrelation.

\subsection{Welfare}

This section compares the welfare performance of the three monetary regimes considered. I compute the welfare gains of moving from the policy regime $r$ to regime $s$ as the proportional increase in consumption for all possible future histories that households living under regime $r$ must receive in order to be indifferent between remaining in regime $r$ and switching to regime $s$. Formally, the welfare gain $\eta$ at a state $\left\{B_{0}, z_{-1}, z_{0}\right\}$ is defined as:

$$
E_{0}\left[\sum_{t=0}^{\infty} \beta^{t} U\left(C_{t}^{r}\left(1+\eta\left(B_{0}, z_{-1}, z_{0}\right)\right), L_{t}^{r}\right)\right]=E_{0}\left[\sum_{t=0}^{\infty} \beta^{t} U\left(C_{t}^{s}, L_{t}^{s}\right)\right]
$$


Table 4: Mean welfare gains of financial stability regime

\begin{tabular}{lcc}
\hline With respect to: & Wage inflation targeting & Currency peg \\
\hline Benchmark & 0.016 & 0.037 \\
No Fisherian deflation & $-7 \times 10^{-5}$ & 0.013 \\
\hline
\end{tabular}

Note: welfare gains are expressed in percent. The welfare gains of moving from the policy regime $r$ to regime $s$ are computed as the proportional increase in consumption for all possible future histories that households living under regime $r$ must receive in order to be indifferent between remaining in regime $r$ and switching to regime $s$.

where the superscripts $r$ and $s$ denote allocations in the economy with the corresponding policy regime. Importantly, this welfare measure takes into account the impact on welfare of the transition to the steady state implied by the new policy.

I start by showing how the presence of the Fisherian deflation mechanism affects the welfare ranking between the strict wage inflation targeting and the financial stability regime. To this end, I compute the welfare gains of moving from a policy of wage inflation targeting to the financial stability regime for the benchmark model, in which the Fisherian deflation channel is present, and for a version of the model in which the collateral constraint (8) is replaced by:

$$
-B_{t+1}^{* i} \leq \kappa \bar{Q} K_{t+1}^{i}
$$

where $\bar{Q}$ is a constant. ${ }^{25}$ In this case households are subject to a fixed borrowing limit, there is no financial amplification and the economy never experiences a financial crisis.

The first column of table 4 shows the average welfare gains in the stochastic steady state of moving from wage inflation targeting to the financial stability regime. Absent the Fisherian deflation channel, wage inflation targeting delivers higher welfare compared to the financial stability regime. Instead, in the benchmark version of the model in which the Fisherian deflation is present the financial stability regime welfare-dominates wage inflation targeting.

To understand this result, consider that with a fixed borrowing limit there are only two sources of inefficiency. First, on average production is inefficiently low due to the presence of monopolistic competition in the labor market. Second, the assumption of nominal wage stickiness may lead to inefficient wedges between the wage rate and the

\footnotetext{
${ }^{25}$ In the numerical simulations $\bar{Q}$ is set equal to the average price of land in the benchmark model with a currency peg.
} 


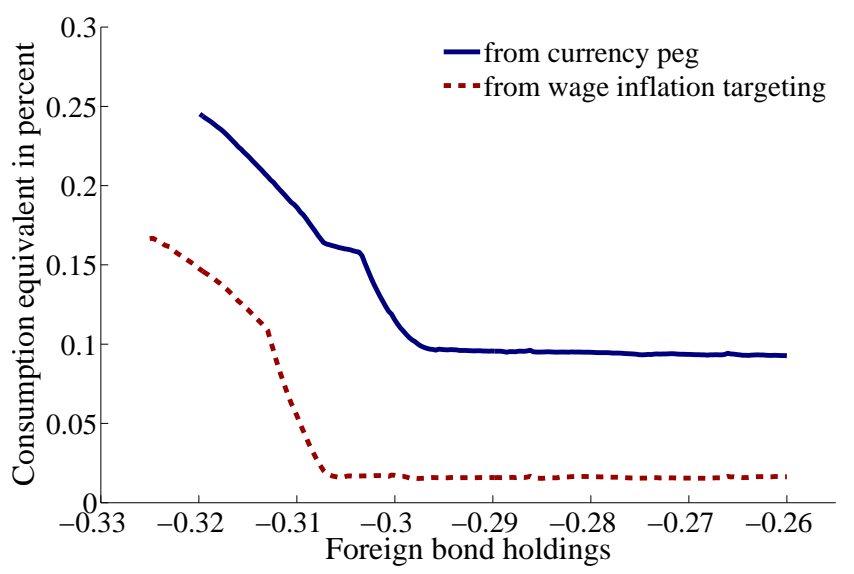

Figure 5: Welfare gains of adopting financial stability regime

marginal rate of substitution between consumption and leisure. These two sources of inefficiency are standard in monetary economics, and it is known that a policy that corrects for nominal rigidities and replicates the equilibrium with flexible wages is close to the optimal policy in this setting. ${ }^{26}$

The Fisherian deflation mechanism introduces another source of inefficiency, based on a pecuniary externality. Atomistic households do not internalize the effect of their actions on the price of land and thus on the value of their collateral. A benevolent social planner that internalizes the impact of its decisions on prices has an incentive to sustain the price of land in states in which the collateral constraint binds, in order to increase the value of the collateral pledgeable to foreign investors. Under the financial stability regime the central bank depreciates the exchange rate in states in which the collateral constraint binds, sustaining the value of land and partly correcting for the pecuniary externality. It is because of this reason that the financial stability regime delivers higher welfare compared to the wage inflation targeting rule in the benchmark model.

The relevance of this source of inefficiency can also be seen by looking at how the welfare gains vary with the initial stock of foreign bonds $B_{0}^{*}$. The dashed line in figure 5 displays the welfare gains of moving from wage inflation targeting to the financial stability regime for the benchmark economy as a function of $B_{0}^{*}$, conditional on a realization of the productivity shock $z_{0}$ about two standard deviations below mean. ${ }^{27}$ The gains from moving from wage inflation targeting to financial stability decrease with the stock of initial

\footnotetext{
${ }^{26}$ See Kollmann (2002) and Schmitt-Grohé and Uribe (2007) for a derivation of this result in presence of monopolistic competition in the product market and nominal price rigidities.

${ }^{27} z_{-1}$ is set equal to its mean value.
} 
bonds. This happens because lower levels of foreign bonds, i.e. higher levels of foreign debt, are associated with higher probability of experiencing a crisis, and so households living in an economy with a low stock of net foreign assets attach more value to the good crisis management properties of the financial stability regime. Indeed, the gains from adopting the financial stability regime become significantly higher for very low levels of initial net foreign assets, because these are the states of the world in which a negative TFP shock triggers a financial crisis.

Quantitatively, the mean welfare gains in the stochastic steady state of moving from a policy of strict wage inflation targeting to the financial stability regime are positive but small, about 0.016 percentage points of permanent consumption. However, they are of the same order of magnitude of the welfare gains from correcting pecuniary externalities found by Bianchi and Mendoza (2010), who study macroprudential policies in a similar setting, and by Ottonello (2013), who considers exchange rate policy in a model featuring a borrowing constraint based on current income. ${ }^{28}$ The small welfare gains from correcting the pecuniary externality can be explained with the low probability of an episode of binding collateral constraint, as well as with the endogenous accumulation of precautionary savings. In fact, as shown by figure 5, for high levels of foreign debt the welfare gains can be more than ten times larger than their mean, and exceed 0.05 percent of permanent consumption, the welfare cost of business cycle calculated by Lucas (2003).

The currency peg is welfare dominated by the other two regimes, both in the benchmark model and when Fisherian deflation is absent. Moreover, the losses associated with the peg are higher when Fisherian deflation is present. These results suggest that the peg does a poor job in managing both normal business cycle fluctuations and crisis events. Indeed, the solid line in figure 5 show that the welfare gains from switching from a currency peg to the financial stability regime are particularly high for high levels of initial debt, because the currency peg amplifies the fall in the price of land and worsens households access to international credit during crises.

The average welfare losses from adopting a peg are quantitatively small. For instance the average gains of switching from the peg to the financial stability regime are 0.037 percentage points of permanent consumption. This is due to the fact that wage contracts

\footnotetext{
${ }^{28}$ Precisely Bianchi and Mendoza (2010) find that the mean gains from correcting the pecuniary externality with macroprudential policy are 0.046 percentage points of permanent consumption, while Ottonello (2013) finds that the mean welfare gains from correcting the pecuniary externality with exchange rate policy are 0.006 percentage points of permanent consumption.
} 


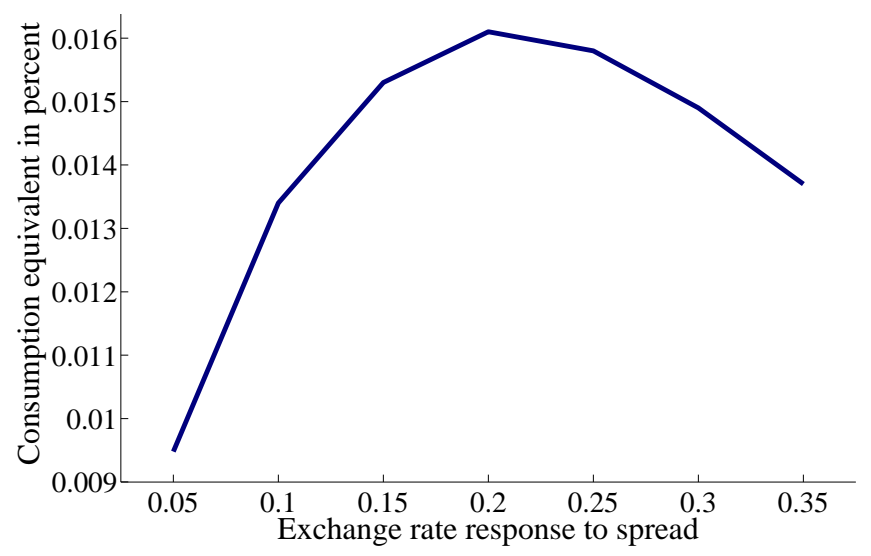

Figure 6: Mean welfare gains of switching from wage inflation targeting to financial stability regime

last only one period in the model. As shown by Schmitt-Grohé and Uribe (2011), persistent downward nominal wage rigidities can lead to substantially higher welfare costs from implementing a currency peg.

\section{Sensitivity analysis and extensions}

This section examines the sensitivity of the main results to changes in some of the key parameters and presents some extensions to the basic framework.

Changes in the exchange rate response to spread. I start by investigating whether the result that the financial stability regime welfare dominates the wage inflation targeting rule in the benchmark version of the model is robust to changes in $\xi_{R}$, the parameter that governs the response of the exchange rate to the spread between domestic and foreign bonds. To this end, I computed the average welfare gains that agents living in the stochastic steady state of the economy with the wage inflation targeting regime would experience from switching to the financial stability regime for a variety of values of $\xi_{R}$. The results, displayed by figure 6 , indicate that the financial stability regime is preferred to a policy of targeting wage inflation over a whole range of values for $\xi_{R}$. As anticipated, among the values of $\xi_{R}$ considered, setting $\xi_{R}$ equal to 0.2 guarantees the highest average welfare gains from adopting a financial stability rule.

Changes in structural parameters. Table 5 presents the sensitivity of the main results of the paper with respect to several parameters. The qualitative results are not affected by changes in the key parameters of the model. In particular, strict wage inflation targeting is always welfare dominated by the flexible exchange rate targeting rule, and 
Table 5: Sensitivity analysis

\begin{tabular}{|c|c|c|c|c|c|c|c|c|c|c|c|c|c|c|}
\hline & \multicolumn{2}{|c|}{ Welfare gains to FS from } & \multicolumn{3}{|c|}{ Crisis probability } & \multicolumn{9}{|c|}{ Mean impact effect of financial crises } \\
\hline & \multirow[b]{2}{*}{ WIT } & \multirow[b]{2}{*}{ PEG } & \multirow[b]{2}{*}{ WIT } & \multirow[b]{2}{*}{ FS } & \multirow[b]{2}{*}{ PEG } & \multicolumn{3}{|c|}{ GDP } & \multicolumn{3}{|c|}{ Consumption } & \multicolumn{3}{|c|}{ Land price } \\
\hline & & & & & & WIT & FS & PEG & WIT & FS & PEG & WIT & FS & PEG \\
\hline benchmark & 0.016 & 0.037 & 5.9 & 10.6 & 5.5 & -2.8 & 0.2 & -5.0 & -6.9 & -1.9 & -9.2 & -9.1 & -4.4 & -10.3 \\
\hline$\gamma=1.9$ & 0.012 & 0.024 & 7.3 & 11.1 & 5.7 & -2.3 & 0.1 & -5.0 & -5.8 & -2.0 & -9.3 & -7.3 & -4.1 & -9.3 \\
\hline$\gamma=2.1$ & 0.019 & 0.036 & 5.6 & 10.0 & 5.4 & -2.8 & 0.4 & -5.0 & -7.2 & -1.9 & -9.2 & -10.0 & -4.8 & -10.7 \\
\hline $1 /(\omega-1)=0.9$ & 0.015 & 0.040 & 6.2 & 10.1 & 5.4 & -2.6 & 0.3 & -5.0 & -6.6 & -1.9 & -9.4 & -8.9 & -4.8 & -10.7 \\
\hline $1 /(\omega-1)=1.1$ & 0.015 & 0.032 & 5.9 & 10.3 & 5.7 & -2.8 & 0.3 & -4.9 & -7.0 & -1.9 & -9.0 & -9.1 & -4.3 & -9.8 \\
\hline$\sigma_{z}=0.015$ & 0.016 & 0.034 & 7.1 & 10.7 & 5.6 & -2.0 & 0.5 & -4.3 & -5.4 & -1.5 & -8.4 & -7.4 & -3.9 & -9.6 \\
\hline$\sigma_{z}=0.02$ & 0.014 & 0.037 & 5.9 & 9.1 & 5.6 & -3.3 & 0.0 & -5.8 & -7.6 & -2.5 & -9.8 & -9.9 & -5.4 & -10.7 \\
\hline$\kappa=0.34$ & 0.008 & 0.028 & 7.1 & 11.2 & 6.5 & -2.4 & 0.1 & -5.0 & -5.7 & -1.9 & -8.4 & -7.7 & -4.3 & -9.4 \\
\hline$\kappa=0.38$ & 0.020 & 0.041 & 5.6 & 10.3 & 5.3 & -2.8 & 0.4 & -5.0 & -7.3 & -1.9 & -9.5 & -9.5 & -4.4 & -10.4 \\
\hline Financial shocks & 0.004 & 0.015 & 5.4 & 6.3 & 5.4 & -1.4 & 0.0 & -2.0 & -6.9 & -5.0 & -7.7 & -9.5 & -4.4 & -10.0 \\
\hline Non-traded sector & $1.6 \times 10^{-4}$ & 0.022 & 13.1 & 13.7 & 10.4 & -1.7 & -1.4 & -4.5 & -1.0 & -0.6 & -4.4 & -0.9 & -0.8 & -1.9 \\
\hline
\end{tabular}

Note: WIT stands for the economy with strict wage inflation targeting, FS stands for the financial stability regime and PEG stands for the currency peg. The other parameters are kept as in the benchmark, except for the model with financial shocks, under which $\xi_{R}=0.03$, and for the model with non-traded sector, in which $\alpha_{T}=0.5, \alpha_{N}=0.75, \psi=0.26, \xi=0.44$ and $\xi_{R}=0.1$. In the model with non-traded sector GDP refers to the foreign currency value of production.

the currency peg is always the regime characterized by the worst performance in terms of welfare. Moreover, the flexible exchange rate targeting rule is always the regime under which crises have the mildest impact on the economy, while the currency peg always features the lowest crisis probability.

However, some parameters have a significant effect on the quantitative results. Indeed, the differences in the welfare performance between the financial stability regime and wage inflation targeting increase significantly if the coefficient of relative risk aversion rises or if the fraction of land holdings that can be offered as collateral increases. These results suggest that different calibrations of the model may yield higher welfare gains from adopting an appropriate monetary policy regime.

Financial shocks. In the benchmark model productivity shocks are the only source of uncertainty. However, sudden stops in small open economies are sometime triggered by developments in the international credit markets. To capture this possibility, I consider shocks to $\kappa$, the fraction of land that can be collateralized. Shocks to $\kappa$ can be interpreted as financial shocks, generating volatility in the country's access to international financial markets. ${ }^{29}$ Specifically, $\kappa$ follows a two-state, regime-switching Markov process with regime values $\kappa_{L}$ and $\kappa_{H} . \kappa_{H}$ is set high enough so that the collateral constraint never binds in that regime. $\kappa_{L}$ is set to 0.32 , which under the currency peg delivers a frequency of financial crises of 5.4 , close to the 5.5 percent of the benchmark model. Denoting by $\rho_{i}$ for $i=H, L$ the probability that $\kappa_{t}=\kappa_{i}$ knowing that $\kappa_{t-1}=\kappa_{i}$, I set the probability of experiencing a bad credit shock to $1-\rho_{H}=0.1$ as in Jeanne and Ranciere (2011), and the probability of exiting an episode of financial turbulence to $1-\rho_{L}=0.5$, following

\footnotetext{
${ }^{29}$ Similar formulations of financial shocks have been studied by Jermann and Quadrini (2012) in closed economies, and by Benigno and Fornaro (2012) and Bianchi (2012) in open economies.
} 
Alfaro and Kanczuk (2009).

The results are shown in table 5. Qualitatively, the results are not affected by the introduction of this type of financial shock. In fact, crises tend to be milder and more frequent under the financial stability regime, while the currency peg is the regime under which crises are more severe and the accumulation of precautionary savings is stronger. Moreover, the financial stability regime welfare-dominates the other two exchange rate regimes considered. Quantitatively, the introduction of this form of financial shocks seems to weaken the inefficiency due to the pecuniary externality. First, the range of values for the parameter $\xi_{R}$ such that the financial stability regime welfare-dominates wage inflation targeting shrinks. Indeed, setting $\xi_{R}=0.2$ as in the benchmark model delivers welfare losses compared to wage inflation targeting, and the results displayed in table 5 refer to a financial stability rule with $\xi_{R}=0.03$. In addition, the welfare gains from adopting a financial stability regime are smaller.

Non-traded sector. The benchmark model considers an economy in which all the consumption goods are perfectly traded. In reality, a large fraction of the goods produced is non-tradable, and some authors have suggested that the hardest hit sectors during financial crises are the ones producing non-traded goods. ${ }^{30}$ Moreover, in certain frameworks the presence of a non-traded sector might create a negative link between depreciations and collateral value. ${ }^{31}$ It is then interesting to check whether the key results of the paper hold in presence of non-traded goods, in particular whether the result that a nominal depreciation has a positive impact on the value of collateral is robust to the introduction of a non-traded sector.

In this section I consider a version of the model in which part of the production has to be consumed domestically. The model is described in details in the appendix, here I quickly review its main features. Consumption is a CES aggregate of a traded and a non-traded good. Production takes place in both sectors. While land is used only by firms operating in the traded sector, labor is employed by firms in both sectors and is perfectly mobile. Importantly, as in the benchmark model I assume that all the debt contracts are denominated in units of the foreign currency and that collateral is given by the foreign currency value of land.

\footnotetext{
${ }^{30}$ For empirical evidence see Tornell and Westermann (2002), while for theoretical models see SchmittGrohé and Uribe (2011) and Fornaro (2012).

${ }^{31}$ See Ottonello (2013).
} 
Potentially, in this version of the model the impact of a nominal depreciation on the foreign currency price of land is ambiguous. To see this point, consider the equivalent of equation (21) which here becomes:

$$
\frac{Q_{t}}{S_{t}}=\frac{\beta E_{t}\left[U_{C}\left(C_{t+1}, L_{t+1}\right) \frac{R_{t+1}^{K}+Q_{t+1}}{P_{t+1}}\right]}{(1-\kappa) \frac{S_{t}}{P_{t}} U_{C}\left(C_{t}, L_{t}\right)+\kappa \beta R^{*} E_{t}\left[\frac{S_{t+1}}{P_{t+1}} U_{C}\left(C_{t+1}, L_{t+1}\right)\right]},
$$

where $P$ denotes the domestic currency price of a unit of consumption, and $P / S$, a measure of the real exchange rate, can be written as:

$$
\frac{P_{t}}{S_{t}}=\psi\left(\psi+(1-\psi)\left(\frac{C_{t}^{T}}{C_{t}^{N}}\right)^{\frac{1-\xi}{\xi}}\right)^{\frac{1}{1-\xi}}
$$

where $C^{T}$ and $C^{N}$ denote respectively the consumption of traded and non-traded good, and $\psi$ and $\xi$ denote respectively the share of the traded good and the elasticity of substitution in the consumption aggregator. ${ }^{32}$

As in the benchmark model, due to nominal wage rigidities a nominal depreciation generates an increase in production in both sectors. If the collateral constraint binds, the increase in production translates into an increase in consumption, which leads to a decrease in the marginal utility from consumption $U_{C}\left(C_{t}, L_{t}\right)$. This effect points toward a positive impact of a nominal depreciation on the foreign currency price of land and on collateral value.

However, with non-traded goods a second effect arises, because a nominal depreciation also affects the foreign currency value of a unit of consumption, $P_{t} / S_{t}$. In fact, if $P_{t} / S_{t}$ decreases after a nominal depreciation there is a channel through which a depreciation can have a negative impact on the foreign currency price of land. Intuitively, if a nominal depreciation generates a decrease in the price of the consumption basket households become more keen to consume in the current period, and the rate at which they discount future returns from land increases, driving down land price.

Ultimately, which effect prevails is a quantitative issue. To parameterize the model with non-traded goods I follow Schmitt-Grohé and Uribe (2011), and set the share of labor in the tradable sector to $\alpha_{T}=0.5$, the share of labor in the non-tradable sector to 0.75 , the share of traded good in the consumption aggregator to $\psi=0.26$ and the

\footnotetext{
${ }^{32}$ Equations (23) and (24) are derived in the online appendix.
} 

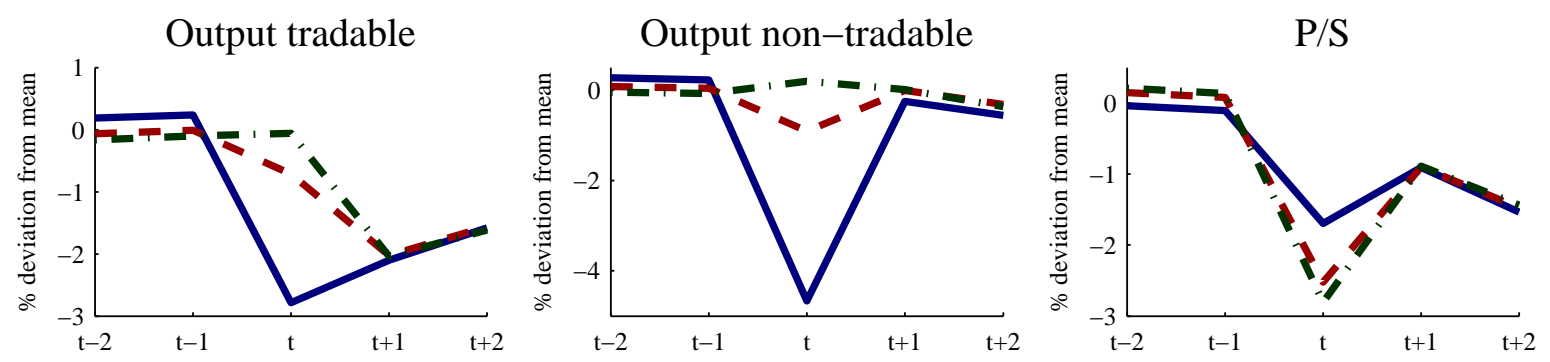

Land price

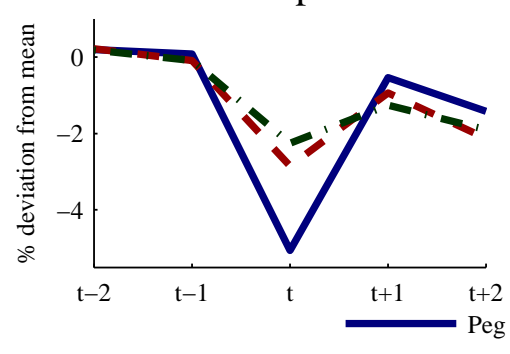

Spread R-R*

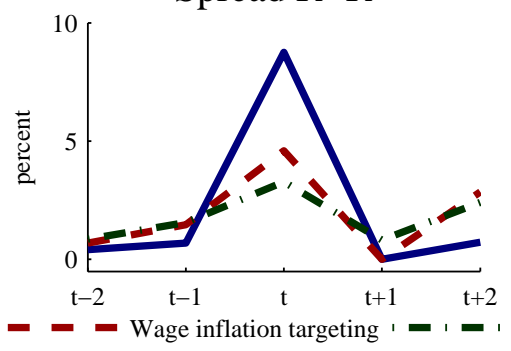

Exchange rate

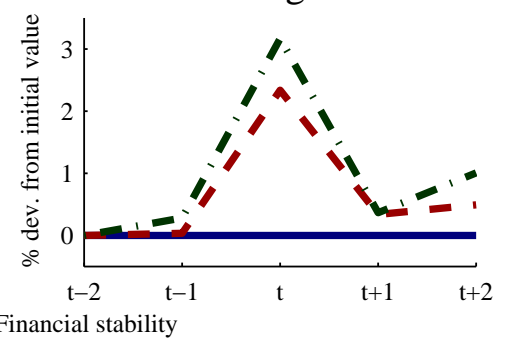

Figure 7: Crisis event analysis with non-traded goods

elasticity of substitution between traded and non-traded goods to $\xi=0.44$. The other parameters are kept as in the benchmark parameterization.

In presence of non-traded goods it is not possible to derive a simple closed form exchange rate rule that replicates the flexible price equilibrium. I thus consider the following in rule. In states $\left\{B_{t}^{*}, z_{t-1}\right\}$ such that the constraint cannot bind for any realization of $z_{t}$ the central bank follows a policy of strict wage inflation targeting. In states $\left\{B_{t}^{*}, z_{t-1}\right\}$ in which the collateral constraint might bind for some realization of $z_{t}$ the central bank follows the rule:

$$
S_{t}=S_{t}^{\text {flex }}\left(\frac{R_{t}}{R^{*}}\right)^{\xi_{R}}
$$

where $S_{t}^{f l e x}\left(B_{t}^{*}, z_{t-1}, z_{t}\right)$ is the equilibrium exchange rate that arises in state $\left\{B_{t}^{*}, z_{t-1}, z_{t}\right\}$ in the model with wage inflation targeting.

I start by investigating the impact of a nominal depreciation on the price of land during crises. Figure 7 presents a typical crisis event in the version of the model with a non-traded sector. ${ }^{33}$

Comparing the wage inflation targeting regime, dashed lines, with the financial stability regime, dash-dotted lines, reveals that a depreciation produces a rise in output in

\footnotetext{
${ }^{33}$ The figure is constructed with the same procedure used to construct figure 2 . To highlight the differences between wage inflation targeting and the financial stability regime, the figure displays a financial stability rule in which $\xi_{R}=0.35$.
} 
both sectors. However, due to the fact that the labor share is bigger in the non-tradable sector than in the tradable one, the impact on the production of non-traded goods is larger. In turn, the nominal depreciation produces a rise in the ratio of consumption of non-traded-to-traded goods, which generates a real exchange rate depreciation, that is a fall in $P / S$. In spite of the real exchange rate depreciation, the price of land rises, because of the positive impact on consumption of the nominal exchange rate depreciation. Hence, also in presence of a non-traded sector the financial stability regime mitigates the fall in the price of land during crisis events and relaxes the collateral constraint, as implied by the fact that the spread rises by less under the financial stability regime compared to wage inflation targeting. We can conclude that the good crisis management properties of the financial stability regime are preserved in the model with a non-traded sector. This result is confirmed by the fact that the financial stability regime delivers the smallest mean falls in land price during crisis events and welfare-dominates the wage inflation targeting rule, as shown in table $5 .^{34}$

\section{Conclusion}

This paper has examined the performance of alternative monetary policy rules in a small open economy model with an occasionally binding collateral constraint that limits access to foreign credit and with nominal wage rigidities. The main finding is that the presence of pecuniary externalities in the credit markets creates a trade-off between price and financial stability. In fact, during a financial crisis the central bank has an incentive to deviate from its traditional objective of offsetting nominal rigidities, in order to take actions that sustain the value of collateral and access to credit. Importantly, this result is derived in a model in which agents rationally take into account the future probability of a crisis and in which exchange rate policy affects precautionary savings and crisis probability.

The paper represents a first step in the analysis of monetary policy in dynamic general equilibrium models featuring tranquil and crisis times driven by Fisherian deflation. Due to the computational complexities involved by the derivation of a global numerical solution, the paper focuses on simple policy rules. An interesting area for future research

\footnotetext{
${ }^{34}$ The financial stability regime shown by the table refers to $\xi_{R}=0.1$, the value of $\xi_{R}$ that maximizes welfare.
} 
would be to derive the optimal exchange rate policy. 


\section{References}

Aghion, P., P. Bacchetta, and A. Banerjee (2004) "A corporate balance-sheet approach to currency crises," Journal of Economic theory, Vol. 119, No. 1, pp. 6-30.

Alfaro, Laura and Fabio Kanczuk (2009) "Optimal reserve management and sovereign debt," Journal of International Economics, Vol. 77, No. 1, pp. 23-36.

Barattieri, A., S. Basu, and P. Gottschalk (2010) "Some evidence on the importance of sticky wages," NBER Working Paper No. 16130.

Benigno, G., H. Chen, C. Otrok, A. Rebucci, and E.R. Young (2011a) "Financial Crisis and Macro-Prudential Policies," CEPR Discussion Paper No. 8175.

(2011b) "Monetary and Macro-Prudential Policies: An Integrated Analysis," Mimeo, London School of Economics.

Benigno, Gianluca and Luca Fornaro (2012) "Reserve Accumulation, Growth and Financial Crises," CEPR Discussion Papers 9224.

Bernanke, B.S. and K. Carey (1996) "Nominal wage stickiness and aggregate supply in the Great Depression," The Quarterly Journal of Economics, Vol. 111, No. 3, pp. $853-883$.

Bianchi, J. (2011) "Overborrowing and Systemic Externalities in the Business Cycle," American Economic Review, Vol. 101, No. 7, pp. 3400-3426.

Bianchi, J. and E.G. Mendoza (2010) "Overborrowing, Financial Crises and Macroprudential Taxes," NBER Working Paper No. 16091.

Bianchi, Javier (2012) "Efficient bailouts?," NBER Working Paper.

Bordo, M.D. and O. Jeanne (2002) "Monetary policy and asset prices: does benign neglectmake sense?" International Finance, Vol. 5, No. 2, pp. 139-164.

Braggion, F., L.J. Christiano, and J. Roldos (2007) "Optimal monetary policy in a sudden stop," Journal of Monetary Economics, Vol. 56, No. 4, pp. 582-595.

Broda, C. (2004) "Terms of trade and exchange rate regimes in developing countries," Journal of International Economics, Vol. 63, No. 1, pp. 31-58. 
Caballero, Ricardo J and Arvind Krishnamurthy (2001) "International and domestic collateral constraints in a model of emerging market crises," Journal of monetary Economics, Vol. 48, No. 3, pp. 513-548.

Caballero, R.J. and A. Krishnamurthy (2003) "Inflation targeting and sudden stops," NBER Working Paper No. 9599.

Calvo, Guillermo A, Alejandro Izquierdo, and Luis-Fernando Mejia (2004) "On the empirics of sudden stops: the relevance of balance-sheet effects," Technical report, National Bureau of Economic Research.

Cespedes, L.F., R. Chang, and A. Velasco (2004) "Balance Sheets and Exchange Rate Policy," The American Economic Review, Vol. 94, No. 4, pp. 1183-1193.

Christiano, L.J., M. Eichenbaum, and C.L. Evans (2005) "Nominal rigidities and the dynamic effects of a shock to monetary policy," Journal of political Economy, Vol. 113, No. 1, pp. 1-45.

Christiano, LJ, C. Gust, and J. Roldos (2004) "Monetary Policy in a Financial Crisis," Journal of Economic Theory, Vol. 119, No. 1, pp. 64-103.

Coleman, W. J. (1990) "Solving the stochastic growth model by policy-function iteration," Journal of Business Economic Statistics, Vol. 8, No. 1, pp. 27-29.

Cook, D. (2004) "Monetary policy in emerging markets: Can liability dollarization explain contractionary devaluations?" Journal of Monetary Economics, Vol. 51, No. 6, pp. $1155-1181$.

Correia, I., J.C. Neves, and S. Rebelo (1995) "Business cycles in a small open economy," European Economic Review, Vol. 39, No. 6, pp. 1089-1113.

Curdia, V. (2007) "Monetary Policy under Sudden Stops," FRB of New York Staff Report No. 278.

Devereux, M.B., P.R. Lane, and J. Xu (2006) "Exchange Rates and Monetary Policy in Emerging Market Economies," The Economic Journal, Vol. 116, No. 511, pp. 478-506. Diaz-Alejandro, Carlos (1985) "Good-bye financial repression, hello financial crash," Journal of development Economics, Vol. 19, No. 1, pp. 1-24. 
Eichengreen, B., P. Gupta, and A. Mody (2006) "Sudden stops and IMF-supported programs," NBER Working Paper No. 12235.

Eichengreen, B. and J. Sachs (1985) "Exchange Rates and Economic Recovery in the 1930s," The Journal of Economic History, Vol. 45, No. 4, pp. 925-946.

Fabiani, S., C. Kwapil, T. Rõõm, K. Galuscak, and A. Lamo (2010) "Wage rigidities and labor market adjustment in Europe," Journal of the European Economic Association, Vol. 8, No. 2-3, pp. 497-505.

Fehr, E. and L. Goette (2005) "Robustness and real consequences of nominal wage rigidity," Journal of Monetary Economics, Vol. 52, No. 4, pp. 779-804.

Fornaro, Luca (2012) "International debt deleveraging," CREI Working Paper.

Gertler, M., S. Gilchrist, and F.M. Natalucci (2007) "External constraints on monetary policy and the financial accelerator," Journal of Money, Credit and Banking, Vol. 39, No. 2-3, pp. 295-330.

Gottschalk, P. (2005) "Downward nominal-wage flexibility: real or measurement error?" Review of Economics and Statistics, Vol. 87, No. 3, pp. 556-568.

Greenwood, J., Z. Hercowitz, and G.W. Huffman (1988) "Investment, capacity utilization, and the real business cycle," The American Economic Review, Vol. 78, No. 3, pp. $402-$ 417.

Jeanne, O. and A. Korinek (2010) "Managing credit booms and busts: A Pigouvian taxation approach," NBER Working Paper No. 16377.

Jeanne, Olivier and Romain Ranciere (2011) "The Optimal Level of International Reserves For Emerging Market Countries: A New Formula and Some Applications," The Economic Journal, Vol. 121, No. 555, pp. 905-930.

Jermann, Urban and Vincenzo Quadrini (2012) "Macroeconomic Effects of Financial Shocks," American Economic Review, Vol. 102, No. 1, pp. 238-71.

Kimball, M.S. and M.D. Shapiro (2008) "Labor Supply: Are the Income and Substitution Effects Both Large or Both Small?," NBER Working Paper No. 14208. 
Kollmann, R. (2002) "Monetary policy rules in the open economy: effects on welfare and business cycles," Journal of Monetary Economics, Vol. 49, No. 5, pp. 989-1015.

Korinek, Anton (2012) "Systemic Risk-Taking: Amplification Effects, Externalities, and Regulatory Responses," Unpublished manuscript.

Lane, P.R. and G.M. Milesi-Ferretti (2007) "The external wealth of nations mark II: Revised and extended estimates of foreign assets and liabilities, 1970-2004," Journal of International Economics, Vol. 73, No. 2, pp. 223-250.

Lucas, Robert E (2003) "Macroeconomic priorities," American Economic Review, Vol. 93, No. 1, pp. 1-14.

Mendoza, E.G. (1991) "Real business cycles in a small open economy," The American Economic Review, Vol. 81, No. 4, pp. 797-818.

_ (2002) "Credit, prices, and crashes: Business cycles with a sudden stop," in Preventing Currency Crises in Emerging Markets: University of Chicago Press, pp. $335-392$.

(2010) "Sudden stops, financial crises, and leverage," The American Economic Review, Vol. 100, No. 5, pp. 1941-1966.

Moron, E. and D. Winkelried (2005) "Monetary policy rules for financially vulnerable economies," Journal of Development Economics, Vol. 76, No. 1, pp. 23-51.

Neumeyer, P.A. and F. Perri (2005) "Business cycles in emerging economies: the role of interest rates," Journal of Monetary Economics, Vol. 52, No. 2, pp. 345-380.

Obstfeld, M. and K. Rogoff (2000) "New directions for stochastic open economy models," Journal of international economics, Vol. 50, No. 1, pp. 117-153.

Olivei, G. and S. Tenreyro (2007) "The timing of monetary policy shocks," The American Economic Review, pp. 636-663.

Ottonello, Pablo (2013) "Optimal Exchange Rate Policy Under Collateral Constraints and Wage Rigidity." 
Schmitt-Grohé, S. and M. Uribe (2007) "Optimal simple and implementable monetary and fiscal rules," Journal of Monetary Economics, Vol. 54, pp. 1702-1725.

_ (2011) "Pegs and Pain," NBER Working Paper No. 16847.

— (2013) "Downward Nominal Wage Rigidity and the Case for Temporary Inflation in the Eurozone," The Journal of Economic Perspectives, Vol. 27, No. 3, pp. 193-211.

Smets, F. and R. Wouters (2003) "An estimated dynamic stochastic general equilibrium model of the euro area," Journal of the European Economic Association, Vol. 1, No. 5, pp. $1123-1175$.

Tauchen, G. and R. Hussey (1991) "Quadrature-based methods for obtaining approximate solutions to nonlinear asset pricing models," Econometrica, Vol. 59, No. 2, pp. 371-396.

Tornell, Aaron and Frank Westermann (2002) "Boom-bust cycles in middle income countries: Facts and explanation," NBER Working Paper No. 9219. 


\section{Appendix}

\section{A Implementation of flexible wage equilibrium}

In this appendix I show that the central bank can implement the flexible wage equilibrium by setting the exchange rate according to:

$$
S_{t}=\bar{S} z_{t}^{\xi_{z}}
$$

with $\xi_{z} \equiv(1-\omega) /\left(\omega-\alpha_{L}\right)$.

Let us start by deriving the labor allocation under flexible wages. With flexible wages, equation (9) holds in any date and state. Using the functional forms assumed, this gives the labor supply equation:

$$
L_{t}^{\omega}=\frac{\sigma-1}{\sigma} \frac{W_{t}}{S_{t}} L_{t}
$$

Firms' labor demand is

$$
\alpha_{L} L_{t}^{\alpha_{L}-1} K^{\alpha_{K}} z_{t}=\frac{W_{t}}{S_{t}}
$$

Combining these two expressions gives the equilibrium labor under flexible wages:

$$
L_{t}=\left(\frac{\sigma-1}{\sigma} \alpha_{L} K^{\alpha_{K}} z_{t}\right)^{\frac{1}{\omega-\alpha_{L}}}
$$

This equation shows that under flexible wages TFP shocks are the only drivers of movements in equilibrium labor.

Now consider the economy with nominal wage rigidities. Let us guess that in every period $t$ anticipating the policy rule $(A .1)$ households set the wage:

$$
W_{t}=\bar{S}\left[\left(\alpha_{L} K^{\alpha_{K}}\right)^{\frac{1-\omega}{\omega-\alpha_{L}}}\left(\frac{\sigma-1}{\sigma}\right)^{\frac{1-\alpha_{L}}{\omega-\alpha_{L}}}\right]^{-1}
$$

Once wages are set, equilibrium labor is determined by firms' labor demand:

$$
L_{t}=\left(\alpha_{L} K^{\alpha_{K}} z_{t} \frac{S_{t}}{W_{t}}\right)^{\frac{1}{1-\alpha_{L}}}
$$

The exchange rate that replicates the labor allocation under flexible wages can be found 
by combining firms' labor demand with equation $(A .4)$ :

$$
S_{t}=W_{t}\left(\alpha_{L} K^{\alpha_{K}} z_{t}\right)^{\frac{1-\omega}{\omega-\alpha_{L}}}\left(\frac{\sigma-1}{\sigma}\right)^{\frac{1-\alpha_{L}}{\omega-\alpha_{L}}}=\bar{S} z_{t}^{\xi_{z}}
$$

where to derive the second equality I used equation $(A .5)$ to substitute out $W_{t}$.

Now we have to show that it is optimal for households to set the wage according to equation (A.5). Given the proposed choices of $W_{t}$ and $S_{t}$ equation (9), the wage setting equation, holds in any date and state, implying that it is optimal for households to set wage according to equation $(A .5)$. This verifies our initial guess.

\section{B Numerical solution method}

Computing the equilibrium involves finding the functions $W\left(B^{*}, z_{-1}\right), L\left(B^{*}, z_{-1}, z\right), C\left(B^{*}, z_{-1}, z\right)$, $B_{+1}^{*}\left(B^{*}, z_{-1}, z\right), Q\left(B^{*}, z_{-1}, z\right), R\left(B^{*}, z_{-1}, z\right)$ that solve the system:

$$
\begin{aligned}
& W=\frac{\frac{\sigma-1}{\sigma} E_{-1}\left[\frac{\left(C-\frac{L^{\omega}}{\omega}\right)^{-\gamma}}{S} L\right]}{E_{-1}\left[\left(C-\frac{L^{\omega}}{\omega}\right)^{-\gamma} L^{\omega}\right]} \\
& L=\min \left[\left(z \frac{S}{W} K^{\alpha_{k}}\right)^{\frac{1}{1-\alpha_{L}}},\left(\frac{W}{S}\right)^{\frac{1}{1-\omega}}\right] \\
& C+B_{+1}^{*}=z L^{\alpha_{L}} K^{\alpha_{K}}+R^{*} B^{*} \\
& -B_{+1}^{*} \leq \kappa \frac{Q}{S} K \\
& \left(C-\frac{L^{\omega}}{\omega}\right)^{-\gamma}=\beta R^{*} E\left(C_{+1}-\frac{L_{+1}^{\omega}}{\omega}\right)^{-\gamma}+\mu \\
& R=\frac{R^{*}}{1-\mu /\left(C-\frac{L^{\omega}}{\omega}\right)^{-\gamma}} \\
& \frac{Q}{S}\left[\left(C-\frac{L^{\omega}}{\omega}\right)^{-\gamma}-\kappa \mu\right]=\beta E\left[\left(C_{+1}-\frac{L_{+1}^{\omega}}{\omega}\right)^{-\gamma}\left(\alpha_{k} L_{+1}^{\alpha_{L}} K^{\alpha_{k}-1}+\frac{Q_{+1}}{S_{+1}}\right)\right] \text {, }
\end{aligned}
$$

for given exchange rate policy $S\left(B^{*}, z_{-1}, z\right)$. The subscripts -1 and +1 denote variables referring respectively to dates $t-1$ and $t+1$.

The solution is approximated numerically by applying the time iteration method proposed by Coleman (1990), adapted to address the occasionally binding collateral con- 
straint as in Bianchi and Mendoza (2010). The algorithm follows these steps:

1. Generate a discrete grid for the net foreign asset position $G_{B^{*}}=\left\{B_{1}^{*}, B_{2}^{*}, \ldots B_{M}^{*}\right\}$ and the productivity shock $G_{z}\left\{z_{1}, z_{2}, \ldots z_{N}\right\}$. I use 300 points for net foreign assets and interpolate the functions using a piecewise linear approximation.

2. Conjecture $W_{J}\left(B^{*}, z_{-1}\right), L_{J}\left(B^{*}, z_{-1}, z\right), C_{J}\left(B^{*}, z_{-1}, z\right), B_{J+1}^{*}\left(B^{*}, z_{-1}, z\right), Q_{J}\left(B^{*}, z_{-1}, z\right)$, $R_{J}\left(B^{*}, z_{-1}, z\right), S_{J}\left(B^{*}, z_{-1}, z\right)$ at time $J \forall B^{*} \in G_{B^{*}}$ and $\forall z \in G_{z}$.

3. Set $y=1$.

4. Solve for $W_{J-y}\left(B^{*}, z_{-1}\right), L_{J-y}\left(B^{*}, z_{-1}, z\right), C_{J-y}\left(B^{*}, z_{-1}, z\right), B_{J-y+1}^{*}\left(B^{*}, z_{-1}, z\right), Q_{J-y}\left(B^{*}, z_{-1}, z\right)$, $R_{J-y}\left(B^{*}, z_{-1}, z\right), S_{J-y}\left(B^{*}, z_{-1}, z\right)$ at time $J-x$ using $(B .1)-(B .6)$ and $W_{J-y+1}\left(B^{*}, z_{-1}\right)$, $L_{J-y+1}\left(B^{*}, z_{-1}, z\right), C_{J-y+1}\left(B^{*}, z_{-1}, z\right), B_{J-y+2}^{*}\left(B^{*}, z_{-1}, z\right), Q_{J-y+1}\left(B^{*}, z_{-1}, z\right), R_{J-y+1}\left(B^{*}, z_{-1}, z\right)$ $S_{J-y+1}\left(B^{*}, z_{-1}, z\right) \forall B^{*} \in G_{B^{*}}$ and $\forall z \in G_{z}$. To deal with the occasionally binding collateral constraint $\forall B^{*} \in G_{B^{*}}$ and $\forall z \in G_{z}$ :

- Assume collateral constraint (B.4) is not binding. Set $\mu_{J-y}\left(B^{*}, z_{-1}, z\right)=0$ and solve for $B_{J-y+1}^{*}\left(B^{*}, z_{-1}, z\right)$ using $(B .5)$.

- Check whether $-B_{+1}^{*} \leq \kappa \frac{Q}{S} K$ holds.

- If constraint is satisfied move to next grid point.

- Otherwise solve for $\mu\left(B^{*}, z_{-1}, z\right)$ and $B_{+1}^{*}\left(B^{*}, z_{-1}, z\right)$ using (B.4) with equality and (B.5).

5. Evaluate convergence. If $\sup _{B^{*}, z_{-1}, z}\left\|x_{J-y}\left(B^{*}, z_{-1}, z\right)-x_{J-y+1}\left(B^{*}, z_{-1}, z\right)\right\|<\epsilon$ for $x=W, L, C, B_{+1}^{*}, Q, R, S$ we have found the solution. Otherwise, set $x_{J-y}\left(B^{*}, z_{-1}, z\right)=x_{J-y+1}\left(B^{*}, z_{-1}, z\right)$ and $y \rightsquigarrow y+1$ and go to step 4 .

\section{Model with non-traded goods}

This section describes in detail the economy with non-traded goods considered in section 4. The basic structure is the same as the benchmark model, but here the economy produces and consumes a tradable good and a non-tradable one. Variables referring respectively to the tradable and the non-tradable sector are denoted with the superscripts $T$ and $N$. 
Firms. A continuum of mass 1 of firms operate in each sector. The production functions are:

$$
\begin{gathered}
Y_{t}^{T}=z_{t}\left(L_{t}^{T}\right)^{\alpha_{T}} K^{\alpha_{k}} \\
Y_{t}^{N}=\left(L_{t}^{N}\right)^{\alpha_{N}},
\end{gathered}
$$

where $Y^{T}$ and $Y^{N}$ denote respectively the output of traded and non-traded good and $0<\alpha_{T}<1,0<\alpha_{K}<1, \alpha_{T}+\alpha_{K}<1$ and $0<\alpha_{N}<1$. For simplicity, I assume that labor $L^{N}$ is the only factor of production employed in the non-tradable sector, while, similar to firms in the benchmark model, firms in the tradable sector employ labor $L^{T}$ and land $K$.

As in the benchmark model, each household supplies a differentiated labor input. $L_{t}^{j}$ for $j=T, N$ is a CES aggregate of the differentiated labor services:

$$
L_{t}^{j}=\left[\int_{0}^{1} L_{t}^{i j \frac{\sigma-1}{\sigma}} d i\right]^{\frac{\sigma}{\sigma-1}},
$$

where $L_{t}^{i j}$ denotes the labor input purchased from household $i$ by firms in sector $j$ and $\sigma>1$. I assume that labor is freely mobile across sectors, implying that household $i$ charges the same wage $W^{i}$ to firms in both sectors. Hence,the minimum cost of a unit of aggregate labor $L_{t}^{j}$ is the same in the two sectors and given by:

$$
W_{t}=\left[\int_{0}^{1} W_{t}^{i 1-\sigma} d i\right]^{\frac{1}{1-\sigma}},
$$

which can be taken as the aggregate nominal wage. Using this definition, profit maximization implies equality between factor prices and marginal productivities:

$$
\begin{aligned}
& W_{t}=S_{t} z_{t} \alpha_{T} \frac{Y_{t}^{T}}{L_{t}^{T}} \\
& R_{t}^{K}=S_{t} z_{t} \alpha_{K} \frac{Y_{t}^{T}}{K_{t}} \\
& W_{t}=P_{t}^{N} \alpha_{N} \frac{Y_{t}^{N}}{L_{t}^{N}},
\end{aligned}
$$

where $S$ and $P^{N}$ denote respectively the domestic currency price of a unit of traded and non-traded good, while $R^{K}$ denote the rental rate of land in units of domestic currency. 
Finally, cost minimization gives the demand for household's $i$ labor from sector $j$ :

$$
L_{t}^{i j}=\left(\frac{W_{t}}{W_{t}^{i}}\right)^{\sigma} L_{t}^{j}
$$

Households. There is a continuum of mass 1 of households. I focus on symmetric equilibria in which per capita and aggregate variables are the same. Hence, to simplify notation, I omit the superscripts $i$. Each household derives utility from consumption $C_{t}$ and experiences disutility from labor effort $L_{t}$, where $L_{t}=L_{t}^{T}+L_{t}^{N}$. The lifetime utility of a generic household is given by:

$$
E_{0}\left[\sum_{t=0}^{\infty} \beta^{t} U\left(C_{t}, L_{t}\right)\right]
$$

In this expression, $E_{t}[\cdot]$ is the expectation operator conditional on information available at time $t$ and $\beta$ is the subjective discount factor. The period utility function $U(\cdot)$ is assumed to be:

$$
U\left(C_{t}, L_{t}\right)=\frac{\left(C_{t}-\frac{L_{t}^{\omega}}{\omega}\right)^{1-\gamma}-1}{1-\gamma}
$$

with $\omega \geq 1$ and $\gamma \geq 1$

Consumption is a CES aggregate of tradable $C^{T}$ and non-tradable $C^{N}$ consumption goods:

$$
C_{t}=\left(\psi\left(C_{t}^{T}\right)^{1-\frac{1}{\xi}}+(1-\psi)\left(C_{t}^{N}\right)^{1-\frac{1}{\xi}}\right)^{\frac{\xi}{\xi-1}}
$$

with $\xi \geq 0$ and $0 \leq \psi \leq 1$. Household optimization implies that the domestic currency price of a unit of consumption basket is:

$$
P_{t}=\left(\psi^{\xi} S_{t}+(1-\psi)^{\xi}\left(P_{t}^{N}\right)^{1-\xi}\right)^{\frac{1}{1-\xi}}
$$

where:

$$
P_{t}^{N}=S_{t} \frac{1-\psi}{\psi}\left(\frac{C_{t}^{T}}{C_{t}^{N}}\right)^{\frac{1}{\xi}}
$$

As in the benchmark model, households have access to domestic and foreign bonds denominated in units of foreign currency. The budget constraint of household $i$ in terms 
of the domestic currency can be written as:

$$
P_{t} C_{t}+S_{t}\left(B_{t+1}^{*}+B_{t+1}\right)+Q_{t}\left(K_{t+1}-K_{t}\right)=W_{t} L_{t}+R_{t}^{K} K_{t}+S_{t}\left(R^{*} B_{t}^{*}+R_{t-1} B_{t}\right)+\Pi_{t}
$$

Moreover, households are subject to the collateral constraint:

$$
-B_{t+1}^{*} \leq \kappa \frac{Q_{t}}{S_{t}} K_{t+1}
$$

Nominal wages are set at the start of the period. Optimal wage setting implies:

$$
-E_{t-1}\left[U_{L}\left(C_{t}, L_{t}\right) L_{t}\right]=\frac{\sigma-1}{\sigma} W_{t} E_{t-1}\left[\frac{U_{C}\left(C_{t}, L_{t}\right)}{P_{t}} L_{t}\right]
$$

Once wages are set, households are willing to satisfy firms' labor demand as long as:

$$
\frac{W_{t}}{P_{t}} \geq-\frac{U_{L}\left(C_{t}, L_{t}\right)}{U_{C}\left(C_{t}, L_{t}\right)}
$$

Given the pre-set wage and the realization of the productivity shock, each period the household chooses $C_{t}, B_{t+1}^{*}, B_{t+1}$ and $K_{t+1}$ to maximize the expected present discounted value of utility $(C .6)$, subject to the budget constraint $(C .10)$ and the collateral constraint (C.11). The optimality conditions are:

$$
\begin{gathered}
\frac{S_{t} U_{C}\left(C_{t}, L_{t}\right)}{P_{t}}=\beta R_{t} E_{t}\left[\frac{S_{t+1} U_{C}\left(C_{t+1}, L_{t+1}\right)}{P_{t+1}}\right] \\
\frac{S_{t} U_{C}\left(C_{t}, L_{t}\right)}{P_{t}}=\beta R^{*} E_{t}\left[\frac{S_{t+1} U_{C}\left(C_{t+1}, L_{t+1}\right)}{P_{t+1}}\right]+\mu_{t} \\
\mu_{t}\left(\kappa \frac{Q_{t}}{S_{t}} K_{t+1}+B_{t+1}^{*}\right)=0 \\
\frac{Q_{t}}{P_{t}} U_{C}\left(C_{t}, L_{t}\right)=\beta E_{t}\left[U_{C}\left(C_{t+1}, L_{t+1}\right) \frac{R_{t+1}^{K}+Q_{t+1}}{P_{t+1}}\right]+\frac{Q_{t}}{S_{t}} \kappa \mu_{t} .
\end{gathered}
$$

Market clearing and equilibrium. Market clearing implies:

$$
C_{t}+B_{t+1}^{*}=Y_{t}^{T}+R^{*} B_{t}^{*}
$$




$$
\begin{gathered}
C_{t}^{N}=Y_{t}^{N} \\
B_{t}^{*}=0 \\
L_{t}=L_{t}^{T}+L_{t}^{N} \\
K_{t}=K,
\end{gathered}
$$

where the last condition derives from the assumption of a fixed endowment of land.

We are now ready to define a rational expectations equilibrium as a set of stochastic processes $\left\{Y_{t}^{T}, L_{t}^{T}, K_{t}, Y_{t}^{N}, L_{t}^{N}, W_{t}, P_{t}^{N}, R_{t}^{K}, C_{t}, C_{t}^{T}, C_{t}^{N}, P_{t}, Q_{t}, B_{t+1}^{*}, B_{t+1}, R_{t}, \mu_{t}\right\}_{t=0}^{\infty}$ satisfying (C.1)-(C.5), (C.7)-(C.9) and (C.12)-(C.22), given the exogenous process $\left\{z_{t}\right\}_{t=0}^{\infty}$, the central bank's policy $\left\{S_{t}\right\}_{t=0}^{\infty}$ and initial conditions $B_{0}^{*}$ and $z_{-1}$.

Derivation of equations (23) and (24). To derive equation (23) combine equations $(C .15)$ and (C.17). Equation (24) is obtained by combining (C.8) and (C.9). 